\title{
Mesoproterozoic diamondiferous ultramafic pipes at Majhgawan and Hinota, Panna area, central India: Key to the nature of sub-continental lithospheric mantle beneath the Vindhyan basin
}

\author{
N V Chalapathi Rao \\ EPMA Laboratory, Mineralogy Section, Ore Dressing Division, Indian Bureau of Mines, Nagpur 440 016, India. \\ e-mail: nvcr100@gmail.com
}

Amongst all the perceptible igneous manifestations (volcanic tuffs and agglomerates, minor rhyolitic flows and andesites, dolerite dykes and sills near the basin margins, etc.) in the Vindhyan basin, the two Mesoproterozoic diamondiferous ultramafic pipes intruding the Kaimur Group of sediments at Majhgawan and Hinota in the Panna area are not only the most conspicuous but also well-known and have relatively deeper mantle origin. Hence, these pipes constitute the only yet available 'direct' mantle samples from this region and their petrology, geochemistry and isotope systematics are of profound significance in understanding the nature of the sub-continental lithospheric mantle beneath the Vindhyan basin. Their emplacement age ( $1100 \mathrm{Ma})$ also constitutes the only reliable minimum age constrain on the Lower Vindhyan Group of rocks. The Majhgawan and Hinota pipes share the petrological, geochemical and isotope characteristics of kimberlite, orangeite (Group II kimberlite) and lamproite and hence are recognised as belonging to a 'transitional kimberlite-orangeite-lamproite' rock type. The name majhagwanite has been proposed by this author to distinguish them from other primary diamond source rocks. The parent magma of the Majhgawan and Hinota pipes is envisaged to have been derived by very small $(<1 \%)$ degrees of partial melting of a phlogopite-garnet lherzolite source (rich in titanium and barium) that has been previously subjected to an episode of initial depletion (extensive melting during continent formation) and subsequent metasomatism (enrichment). There is absence of any subduction-related characteristics, such as large negative anomalies at $\mathrm{Ta}$ and $\mathrm{Nb}$, and therefore, the source enrichment (metasomatism) of both these pipes is attributed to the volatile- and K-rich, extremely low-viscosity melts that leak continuously to semi-continuously from the asthenosphere and accumulate in the overlying lithosphere. Lithospheric/crustal extension, rather than decompression melting induced by a mantle plume, is favoured as the cause of melting of the source regions of Majhgawan and Hinota pipes. This paper is a review of the critical evaluation of the published work on these pipes based on contemporary knowledge derived from similar occurrences elsewhere.

\section{Introduction}

Potassic-ultrapotassic, volatile-rich, ultramafic rock types such as kimberlite (Group I kimberlite), orangeite (Group II kimberlite) and lamproite are relatively small-volume intra-plate alkaline magmas and are extremely rare in geological history. These magmas are generated at great depths (150-200 km) and, during their ascent to the Earth's surface, often also incorporate a variety of mantle and crustal xenoliths. It is these rare and exotic rocks, and not their much more voluminous

Keywords. Kimberlite; lamproite; orangeite; diamond; proterozoic; Majhgawan; Hinota; Panna; Vindhyan basin; India.

J. Earth Syst. Sci. 115, No. 1, February 2006, pp. 161-183

(C) Printed in India. 
counterparts such as flood basalts, which provide the most direct information about the composition of the deeper parts of the continental lithosphere and hence serve as 'windows' to the Earth's mantle. Although a number of other rock types have recently been identified as potential hosts for diamonds (e.g., Kaminsky et al 2004), the status of kimberlites, orangeites and lamproites as the principal primary hosts of diamonds as yet remains undisputed.

Kimberlites, orangeites and lamproites are commonly considered to be extreme products of mantle enrichment processes and have very high abundances of trace elements. Due to their high abundances of both compatible (e.g., Ni, Cr) and incompatible trace elements (e.g., Nb, Ta, Zr, La, Sr), relative to common crustal rocks, open system processes such as crustal contamination are widely believed to have little or no effect on the pristine trace element composition of these rocks (e.g., Hawkesworth et al 1985; Fraser 1987; Mitchell 1995a). Recent studies have shown that the geochemistry of kimberlite, lamproite and orangeite can be used to investigate the relative contributions of asthenosphere- and lithosphere-derived melts and to probe the compositional variation in the continental lithospheric mantle (e.g., Gibson et al 1995; Beard et al 2000). Variable amounts of initial melt depletion prior to subsequent metasomatic enrichment have also been recognized in the source regions of kimberlites, orangeites and lamproites (e.g., Tainton and McKenzie 1994; Carlson et al 1996; Chalapathi Rao et al 2004). Hence, the latter's composition serve as key to our understanding of the nature of the underlying continental lithospheric mantle.

The main purpose of this paper is to review the petrology and geochemistry of two of central India's most celebrated Mesoproterozoic diamondiferous ultramafic pipes (considered in this paper to belong to transitional kimberlite-lamproiteorangeite rock type - majhgawanite) which intrude the Lower Vindhyan SuperGroup of rocks at Majhgawan and Hinota in the Panna area. Another objective is to infer the petrogenesis of these bodies so as to understand the nature of the continental lithospheric mantle beneath the Vindhyan basin at the time of their emplacement. The ultimate objective is to discuss the origin of the Majhgawan and Hinota pipes vis-a-vis the evolution of the Lower Vindhyan basin.

\section{Igneous activity in the Vindhyan basin}

The Vindhyan basin is the largest among the Proterozoic (Purana) sedimentary basins of peninsular
India in terms of its area. However, igneous activity during the deposition of the Vindhyan sediments is insignificant in comparison to that in other Purana basins of India such as Cuddapah basin. A review of the existing literature (e.g., Krishnan and Swaminath 1959; Soni et al 1987; Kale 1991; Bhattacharya 1996 and the references therein; Anil Kumar et al 2001b; Ray et al 2003) reveals that the perceptible igneous activity is predominantly confined to the Lower Vindhyans (Semri and Kaimur Groups) and in the Upper Vindhyans (Rewa and Bhander Groups), where it is manifested in minor felsic to intermediate volcani-clastics occurring as ash fall and flow deposits as well as epiclastics (see Chakraborty et al 1996). Igneous manifestations in the Vindhyan basin can be broadly categorized into the following types:

- minor rhyolitic tuffs and volcanic agglomerates in the Son valley (Banerjee 1964),

- volcanic tuffs in the Chitrakut area, Banda district (Hukku 1971),

- doleritic dykes and sills mostly along the margins, but not within the interior, of the Vindhyan basin in the Narmada and Son valleys (Auden 1933; Ahmed 1971; Soni et al 1987),

- andesites and a minor lamprophyre (kersantite) sill in the Rajasthan area (Prasad 1976, 1981) and

- diamondiferous ultramafic pipes at Majhgawan and Hinota in the Panna area (e.g., Mathur and Singh 1971; Paul 1991; Scott-Smith 1989; Ravi Shanker et al 2001; Chalapathi Rao 2005).

From the above, it is evident that with the exception of the diamondiferous ultramafic pipes at Majhgawan and Hinota, none of the other igneous activities appear to have relatively deep seated (mantle) origin. Hence, the petrology and geochemistry of the former assumes great significance in probing the nature of the underlying continental lithospheric mantle beneath the Vindhyan basin in Mesoproterozoic time.

\section{Previous studies on the Majhgawan and Hinota pipes}

The diamondiferous Majhgawan pipe $\left(24^{\circ} 38^{\prime} 30^{\prime \prime} \mathrm{N}\right.$ : $80^{\circ} 02^{\prime} \mathrm{E}$; figure 1 ) in the Panna area of central India, which accounts for nearly $99 \%$ of India's diamond production, was reported by Captain J Franklin as early as in 1827 (see Halder and Ghosh 1978, p. 2). This was some 60 years prior to the time when the word 'kimberlite' was coined by Henry Carvill Lewis (1887) for the primary source rock for diamonds in South Africa. However, it should be mentioned here that diamond has been known from the Panna area for several 


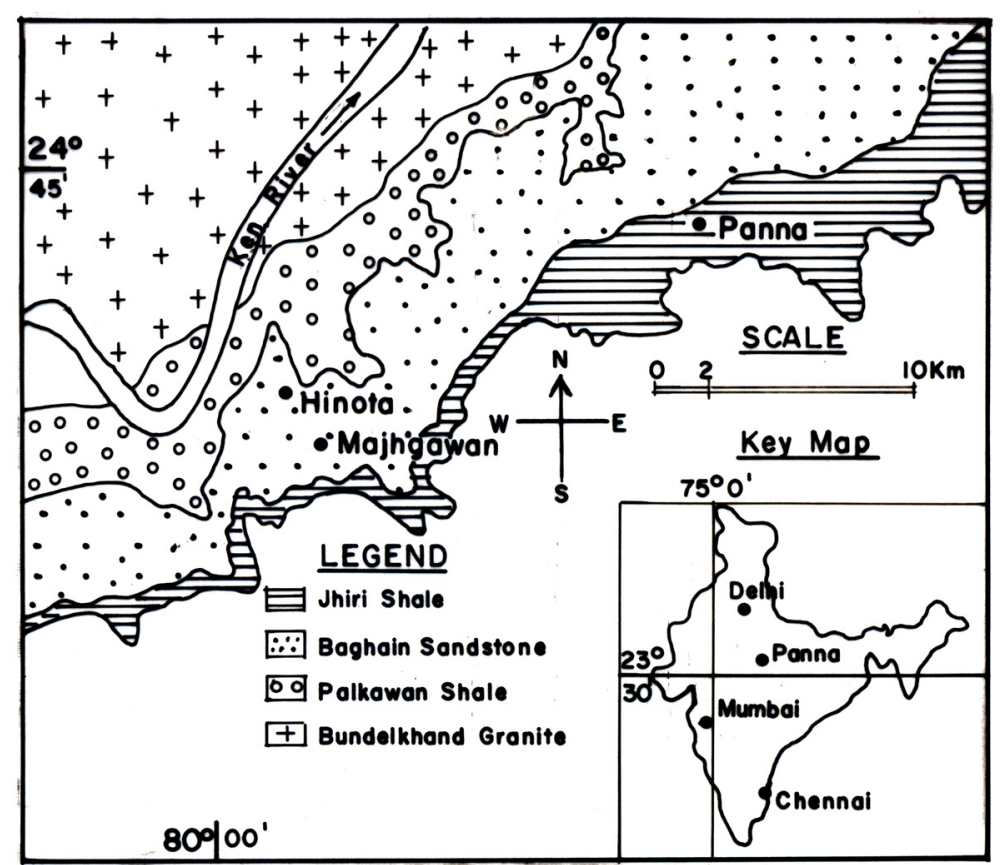

Figure 1. Location of the Majhgawan and Hinota pipes in the Vindhyan basin of central India (adopted from Chatterjee and Rao 1995).

centuries and historical records establish that mining activity was at its peak during the reign of Mughal emperor Akbar the Great (Chaterji 1971). At Hinota $\left(24^{\circ} 39^{\prime} \mathrm{N}\right.$ : $80^{\circ} 02^{\prime} \mathrm{E}$; figure 1$)$, which is about $3 \mathrm{~km}$ from Majhgawan, another diamondiferous minor ultramafic pipe was located using magnetic and electrical resistivity surveys by the Geological Survey of India (GSI) during 19561959 and it is considered to be a satellite body of Majhgawan pipe (Kailasam 1971).

Much of the early work on the Majhgawan pipe was mainly concerned with its economic aspects and preliminary petrography (e.g., Medlicott 1859; Dubey and Merh 1949; Merh 1952; Mathur 1953, 1958; Mathur and Singh 1963). Sinor (1930) referred to it as 'agglomeritic tuff' whereas Dasgupta and Phukan (1971) preferred to term it 'serpentine rock'. However, it was recognised to be a kimberlite or 'micaceous kimberlite' (cf. Wagner 1914), along with that of Hinota, only in the 1970s (Mathur and Singh 1971; Paul et al 1975a, b; Halder and Ghosh 1978, 1981) and continued to be referred to by that name for more than a decade until Scott-Smith (1989) assigned a lamproitic status to it (and to the Hinota pipe) based on petrography and mineral chemistry (see below). Kharikov et al (1991) and Chatterjee and Rao (1995), however, opined that the geologic, petrographic and geochemical features of Majhgawan pipe rocks were intermediate in several aspects between typical kimberlite and lamproite.

Recently, Ravi Shanker et al (2001, 2002), based on petrological and geochemical grounds, re-classified the Majhgawan and Hinota pipes as orangeite (Group II kimberlite of South Africa). However, both the pipe rocks lack essential geochemical criteria such as per-alkaline and perpotassic indices as required by the typical orangeite (see Madhavan 2002). In the most recent study, Chalapathi Rao (2005) demonstrated that the Majhgawan pipe cannot be uniequivocally characterized as a kimberlite or orangeite or lamproite and, in fact, inherits the traits of all these above three rocks. Hence, Chalapathi Rao (2005) has suggested that it constitutes a transitional kimberliteorangeite-lamproite rock type and also proposed the name majhgawanite - keeping in mind the antiquity of the Majhgawan pipe, its intriguing petrological and geochemical characteristics and also India's legacy of diamond to the world.

\section{Geology and structural aspects of Majhgawan and Hinota pipes}

The Majhgawan and Hinota pipes intrude the Baghan Quartzite Formation of the Kaimur Group which is a part of the Vindhyan Supergroup (figure 1). The Vindhyan Supergroup comprises Mesoto mid Neo-Proterozoic rocks with an age range from $1631 \pm 8 \mathrm{Ma}$ (Ray et al 2003) to $\sim 550 \mathrm{Ma}$ (Crawford and Compston 1970). The Vindhyan sediments overlie the Archaean basement of the Bundelkhand craton comprising primarily granites and gneisses along with small enclaves of older metamorphic rocks and basic and ultrabasic 
Table 1. Radiometric age determinations of the Majhgawan and Hinota pipes.

\begin{tabular}{lll}
\hline Radiometric method & Age (Ma) $2 \sigma$ & \multicolumn{1}{c}{ Reference } \\
\hline $\begin{array}{l}\text { Majhgawan pipe } \\
\text { K-Ar (Phlogopite) }\end{array}$ & 1056 & McDougall in Crawford and Compston (1970) \\
Rb-Sr (Phlogopite) & $1140 \pm 20^{*}$ & Crawford and Compston (1970) \\
K-Ar (Whole-rock) & $974-1170$ & Paul et al (1975a) \\
Rb-Sr (Whole-rock) & $1630 \pm 353$ & Paul (1979) \\
Rb-Sr (Phlogopite) & $1044 \pm 22$ & C B Smith in Anil Kumar et al (1993) \\
Rb-Sr (Phlogopite) & $1067 \pm 31$ & Anil Kumar et al (1993) \\
Hinota pipe & & \\
K-Ar (Whole-rock) & $1170 \pm 46$ & Paul et al (1975a) \\
\hline
\end{tabular}

intrusive rocks (Naqvi and Rogers 1987). The southern margin of the Vindhyan basin is flanked by a major tectonic lineament of the Indian sub-continent, the Narmada-Son lineament, which is considered to have been formed along the Archaean structural trends and to have remained active throughout geological history till the present day (Naqvi and Rogers 1987; Chakraborty and Bhattacharya 1996). Seismic investigations have revealed the existence of several E-W oriented deep fractures underlying the Vindhyans, some of which extend down to the Moho (Kaila et al 1989). These fractures have been interpreted to be of Archaean age and vertical movements along them have been inferred to be operational at different times during the deposition of the Vindhyan sediments (Kaila et al 1989).

The Majhgawan pipe occurs on the western limit of the Panna diamond belt $(80 \times 50 \mathrm{~km})$ and is localized in a NE-SW to ENE-WSW trending crestal zone of the upwarped eastern margin of the Bundelkhand craton (Halder and Ghosh 1978). According to Janse (1992) the Majhgawan pipe is located at the margin of the Aravalli Archon. The Majhgawan pipe is pear shaped on the surface with dimensions of $500 \mathrm{~m} \times 330 \mathrm{~m}$ with its western end showing a slight pointed bulge (Halder and Ghosh 1978). The payable body is elliptical in shape, $320 \mathrm{~m} \times 280 \mathrm{~m}$ in size and has a surface area of $0.065 \mathrm{~km}^{2}$ (Indian Bureau of Mines 1996). This pipe has been drilled to a depth of about $250 \mathrm{~m}$ and it has the shape of a cone and the contact with the host rock dips at fairly constant angle of $70^{\circ}$ to $80^{\circ}$ inwards (Chatterjee and Rao 1995). The Hinota pipe is a circular intrusion with a shallow crater of up to $80 \mathrm{~m}$. Even though the shape of the Majhgawan and Hinota pipes is dissimilar to that of many known lamproite occurrences (Mitchell and Bergman 1991), it should be mentioned here that the highly diamondiferous Argyle lamproite (also of Mesoproterozoic age) in western Australia also has steep contacts with the host rocks (Jaques et al 1989). Thus, the Majhgawan and Hinota pipes are more similar in shape and form to kimberlites than lamproites, as the former in all cases have diatremes sloping at an average $82^{\circ}$ - the shape of all deep explosive vents.

From an extensive study of about 450 kimberlites, lamproites and lamprophyres in Australia, Jaques and Milligan (2003) have recently concluded that typical kimberlites occur within and at the margin of the Archaean cratons, lamproites at the cratonic margins and near mobile belts and lamprophyres at margins of cratons only. Likewise Skinner et al (1992), from the distribution of 229 orangeites and 580 archetypal kimberlites in the Kaapvaal craton of southern Africa have shown that orangeite (Group II kimberlite) occurrences are found predominantly at the edge of the Kaapvaal craton whereas those of kimberlites are characteristically confined to on-cratonic settings. Thus, it can be inferred that the location of the Majhgawan and Hinota pipes at the cratonic margin of the Bundelkhand craton has more similarities to the tectonic setting of a lamproite or orangeite than a kimberlite.

\section{Emplacement age of the Majhgawan and Hinota pipes}

Radiometric age determinations of Majhgawan and Hinota pipes carried out by different workers are summarized in table 1 . $\mathrm{K}-\mathrm{Ar}$ (whole rock), $\mathrm{Rb}-\mathrm{Sr}$ (phlogopite separates as well as whole-rock) ages are available for Majhgawan pipe whereas there is only a single $\mathrm{K}-\mathrm{Ar}$ whole-rock age for the Hinota pipe. Considering that the whole rock ages are likely to be less reliable than the age determinations made on the groundmass phlogopite mineral separates, the age of Majhgawan pipe can be accepted to be close to $1100 \mathrm{Ma}$. The single available $\mathrm{K}-\mathrm{Ar}$ age for the Hinota pipe is $1170 \pm 46 \mathrm{Ma}$ (Paul et al 1975a). Since this is obtained on a whole-rock, it is believed that its true age is likely to be less and contemporaneous (within the error 
Table 2. Summary of mineralogy of Majhgawan and Hinota ultramafic pipes.

\begin{tabular}{|c|c|c|}
\hline Mineral/habit & Nature of occurrence & References \\
\hline $\begin{array}{l}\text { Olivine: } \\
\text { Macrocryst } \\
\text { Phenocryst }\end{array}$ & $\begin{array}{l}\text { Present (complex shaped) } \\
\text { Abundant (crystal aggregates) } \\
\text { Both types of olivines are thoroughly serpentinised; } \\
\text { in fact, no fresh olivines ever reported }\end{array}$ & $\begin{array}{l}\text { Kresten and Paul (1976), } \\
\text { Middlemost and Paul (1984), } \\
\text { Scott-Smith (1989) }\end{array}$ \\
\hline $\begin{array}{l}\text { Mica (Phlogopite): } \\
\text { Macrocryst } \\
\text { Phenocryst } \\
\text { Groundmass }\end{array}$ & $\begin{array}{l}\text { All the three types of grains present } \\
\text { Phenocrystal and groundmass micas are typically Fe and } \\
\text { Ti-enriched and Al-poor }\end{array}$ & $\begin{array}{l}\text { Middlemost and Paul (1984), } \\
\text { Scott-Smith (1989), } \\
\text { Ravi Shanker et al (2002) }\end{array}$ \\
\hline Spinels & $\begin{array}{l}\text { Magnetite, magnesio-chromite and titano-magnetite } \\
\text { present }\end{array}$ & Ravi Shanker et al (2002) \\
\hline Diopside & Clinopyroxene microlites present & $\begin{array}{l}\text { Soni et al (1987), } \\
\text { Scott-Smith (1989) }\end{array}$ \\
\hline Perovskite & Rare and occurs as microphenocrysts and in groundmass & $\begin{array}{l}\text { Middlemost and Paul (1984), } \\
\text { Soni et al }(1987) \\
\text { Scott-Smith (1989) }\end{array}$ \\
\hline Apatite & Common (F-rich) & Kresten and Paul (1976) \\
\hline Carbonates & $\begin{array}{l}\text { Both primary and secondary varieties of calcite present. } \\
\text { Minor dolomite present }\end{array}$ & $\begin{array}{l}\text { Kresten and Paul (1976), } \\
\text { Ravi Shanker et al (2001), } \\
\text { Middlemost and Paul (1984) }\end{array}$ \\
\hline Serpentine & Abundant; secondary (mostly lizardite) & $\begin{array}{l}\text { Kresten and Paul (1976), } \\
\text { Middlemost and Paul (1984), } \\
\text { Scott-Smith (1989), } \\
\text { Ravi Shanker et al (2002) }\end{array}$ \\
\hline Mn-Ilmenite & $\begin{array}{l}\text { Present (Mg-rich and Mn-poor) as microphenocrysts and } \\
\text { as groundmass constitutent }\end{array}$ & $\begin{array}{l}\text { Middlemost and Paul (1984), } \\
\text { Ravi Shankar et al (2002) }\end{array}$ \\
\hline Barite & $\begin{array}{l}\text { Common as groundmass phase and occurs as late-stage } \\
\text { deuteric hydrothermal alteration product }\end{array}$ & $\begin{array}{l}\text { Middlemost and Paul }(1984) \text {, } \\
\text { Ravi Shankar et al }(2001,2002)\end{array}$ \\
\hline Rutile & $\begin{array}{l}\text { Present (Nb-poor and Cr-poor) occurs as micro- } \\
\text { phenocrysts and as microlites in the groundmass }\end{array}$ & Ravi Shankar et al (2002) \\
\hline Glass & Present as shards in the groundmass & Scott-Smith (1989) \\
\hline Quartz & Present as minor phase in the groundmass & $\begin{array}{l}\text { Halder and Ghosh (1981); } \\
\text { Ravi Shanker et al (2001) }\end{array}$ \\
\hline $\begin{array}{l}\text { Monazite } \\
\text { Sulphides }\end{array}$ & $\begin{array}{l}\text { Present as rare groundmass phase } \\
\text { Pyrite, chalcopyrite, sphalerite and pentlandite occur as } \\
\text { plates, laths and inclusions in ilmenites and serpentinised } \\
\text { olivines }\end{array}$ & $\begin{array}{l}\text { Ravi Shanker et al }(2001,2002) \\
\text { Ravi Shanker et al (2002) }\end{array}$ \\
\hline
\end{tabular}

limits) with that of Majhgawan. The age of the Majhgawan and Hinota pipes also constitutes the only reliable minimum age constraint on the deposition of the Lower Vindhyan Group of rocks.

Available radiometric data suggest that all the Indian kimberlites and lamproites, dated till now, are of Proterozoic age (Chalapathi Rao et al 2004). However, orangeites have been reported from the Damodar valley yielding ${ }^{40} \mathrm{Ar} /{ }^{39} \mathrm{Ar}$ ages ranging from 109-116 Ma (Kent et al 1998). Thus, the emplacement age of the Majhgawan and Hinota pipes is similar to that of Proterozoic archetypal kimberlites and lamproites of India but very different to that of an orangeite.

\section{Mineralogy and petrography}

Detailed petrological studies on the Majhgawan pipe have been carried out by a number of previous workers (e.g., Mathur and Singh 1971; Dasgupta and Phukan 1971; Paul et al 1975a; Kresten and 







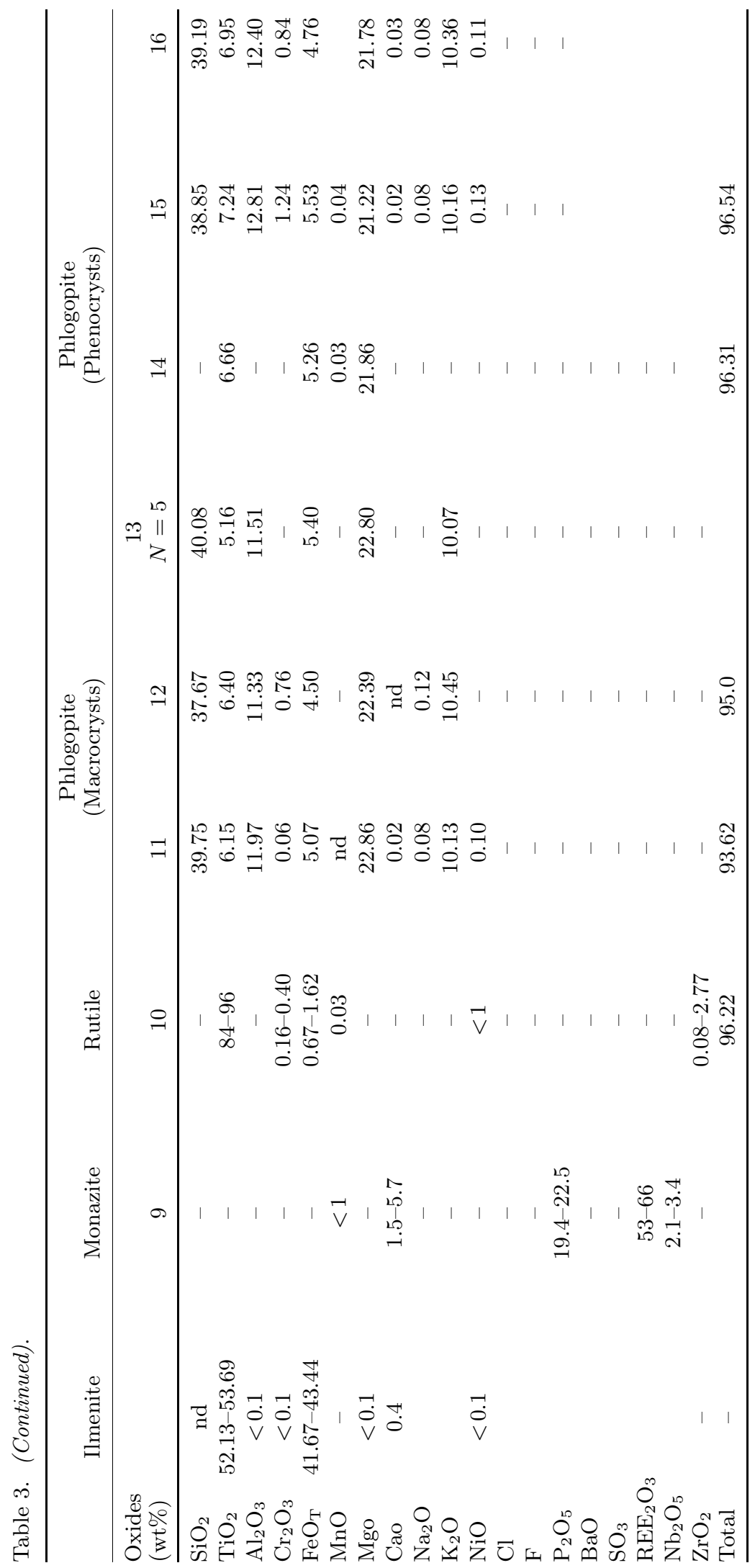


Paul 1976; Haldar and Ghosh 1978, 1981; Middlemost and Paul 1984; Gupta et al 1986; Scott-Smith 1989 and Ravi Shanker et al 2001, 2002). All these studies have revealed that the rock material so far obtained from Majhgawan pipe represents different varieties of magmaclastic agglomeritic tuff. The tuffs contain juvenile lapilli or magmaclasts which could be described as being of magmatic derivation. These magmaclasts are macrocrystic in nature as they contain two generations of altered olivine, viz., large, anhedral and corroded macrocrysts (which could be xenocrysts) as well as subhedral to euhedral phenocrysts (representing primary olivines grown out of the magma). Both these altered olivine types are set in a fine to cryptocrystalline, brownish and turbid groundmass predominantly consisting of the serpentine group of minerals, iddingsite, phlogopite, glass, apatite, carbonate minerals (calcite and dolomite), illite, vermiculite, montmorillonite, polygarskite, perovskite, rutile, chlorite, spinel group of minerals, barite and diamond. The groundmass occasionally contains vesicles and juvenile lapilli tuffs. The pipe rock is also traversed by numerous veinlets of calcite, especially in the upper most portion.

Mineralogy and petrography of the Hinota pipe duplicates that of the Majhgawan pipe. However, the samples are relatively more altered and exhibit extensive carbonation (Scott-Smith 1989; see also table 4) and hence no mineral chemistry data for them are available. Much of the earlier mineralogical data on the Majhgwan and Hinota pipe rocks were obtained by the conventional optical microscopy by employing transmitted and reflected light methods. Hence, only such data generated by various thermal, electron beam and X-ray methods are summarized in table 2 . The representative compositions of various mineral phases, where available, are provided in table 3 and the salient petrographic aspects of individual mineral phases are discussed as under.

\section{- Olivine}

Olivine has been completely altered (Dasgupta and Phukan 1971; Paul 1991). Serpentine and iddingsite form important alteration products (Mathur and Singh 1971). The macrocrystal olivines (mostly $<5 \mathrm{~mm}$, but rarely up to $10 \mathrm{~mm}$ ) are predominantly anhedral and occasionally subhedral. The smaller phenocrysts $(<0.5 \mathrm{~mm})$ are euhedral. A few of the megacrysts have also been replaced by carbonates (Middlemost and Paul 1984). Some of the olivine macrocrysts exhibit complex shapes (probably imposed morphology) whereas certain phenocrysts occur as crystal aggregates. Scott-Smith (1989) considers such olivines to be atypical of kimberlites but similar to those of olivine lamproites at Ellendale and Argyle of western Australia (Jaques et al 1986), Prairie Creek in Arkansas (Scott-Smith and Skinner 1984) and Kapamba in Zambia (Scott-Smith et al 1989).

\section{- Serpentine}

Serpentine occurs predominantly as an alteration product pseudomorphous after olivine and its chemical composition is more or less constant (table 3) with high $\mathrm{FeO}_{\mathrm{T}}$ contents (6.30 to $9.26 \mathrm{wt} \%)$ and corresponds to that of a lizardite. Middlemost and Paul (1984) remark that such high-Fe serpentines are unique to kimberlites (cf Emeleus and Andrews 1975).

\section{- Phlogopite}

Distribution of phlogopite in the Majhgawan pipe is erratic but it constitutes an important phase (Paul et al 1975a). Phlogopites in both the pipes are generally pleochroic ranging from pale brown to orangish colour. Phlogopites of three paragenesis have been recorded: (i) macrocrysts (up to $4 \mathrm{~mm}$ ), which are anhedral to subhedral in form and are erratically distributed, (ii) phenocrysts (up to $1.5 \mathrm{~mm}$ ) which are most abundant and occur as slender laths with a majority of them displaying polysynthetic twinning and (iii) groundmass microphenocrysts $(0.04 \mathrm{~mm})$ present as lath-like equant crystals (Middlemost and Paul 1984; Scott-Smith 1989). Coarser phlogopites (macrocrysts) are rare in the Hinota pipe (Scott-Smith 1989). There is little difference in the composition of macrocrysts and phenocrysts (table 3) except for relatively high $\mathrm{TiO}_{2}$ and $\mathrm{FeO}_{\mathrm{T}}$ contents in case of phenocrysts. Their $\mathrm{Mg} \#$ is $>80$. The phlogopites are clearly titaniam-enriched in contrast to the titanium-poor micas of archetypal kimberlites (Mitchell 1995a). In the $\mathrm{TiO}_{2}$ versus $\mathrm{Al}_{2} \mathrm{O}_{3}$ (wt\%) bivariate plot (figure 2) the phlogopites of the Majhgawan pipe are compositionally very similar to the lamproite micas (Scott-Smith 1989), and not so similar to those from archetypal kimberlites, orangeites and MARID-suite of xenoliths. No microprobe data of phlogopites are available for Hinota pipe.

\section{- Glass}

Devitrified glass constitutes an important phase in the groundmass (Mathur and Singh 1971; ScottSmith 1989) and its composition is given in table 3. Low totals for glass are probably due to high water content. The occurrence of glass is uncommon in archetypal kimberlites and orangeites (Kent et al 1998) but well known from lamproites (Scott-Smith 
Table 4. Major element (oxide weight percentages) data of the Majhgawan pipe.

\begin{tabular}{|c|c|c|c|c|c|c|c|c|c|c|c|c|}
\hline \multirow{2}{*}{$\begin{array}{c}\text { Major } \\
\text { oxides (wt\%) }\end{array}$} & \multicolumn{8}{|c|}{ Majhgawan } & \multicolumn{4}{|c|}{ Hinota } \\
\hline & MJW & M & $\mathrm{M} / \mathrm{A}$ & $\operatorname{Mg} 6$ & MG 50 & UG 11a & UG 191 & 7 & $\mathrm{HV}-1 / 3$ & $\mathrm{HV}-4 / 2$ & $\mathrm{HV}-4 / 6$ & $\mathrm{H} / 1$ \\
\hline $\mathrm{SiO}_{2}$ & 37.94 & 34.82 & 33.97 & 36.29 & 34.82 & 34.90 & 36.50 & 33.69 & 35.22 & 30.99 & 35.12 & 34.48 \\
\hline $\mathrm{TiO}_{2}$ & 4.79 & 5.7 & 5.47 & 5.11 & 4.62 & 5.51 & 3.76 & 6.04 & 8.74 & 9.51 & 6.24 & 8.10 \\
\hline $\mathrm{Al}_{2} \mathrm{O}_{3}$ & 2.90 & 2.88 & 2.51 & 2.63 & 3.93 & 2.79 & 6.07 & 3.28 & 5.16 & 4.61 & 3.86 & 3.14 \\
\hline $\mathrm{Fe}_{2} \mathrm{O}_{3}^{*}$ & 8.94 & 10.49 & 7.34 & 6.39 & 4.42 & 6.62 & 3.87 & - & 10.24 & 14.16 & 3.40 & 5.40 \\
\hline $\mathrm{FeO}$ & - & - & 3.50 & 2.32 & 3.06 & 3.22 & 3.85 & 10.98 & 6.71 & 5.91 & 4.69 & 3.80 \\
\hline $\mathrm{MnO}$ & 0.14 & 0.19 & 0.08 & 0.14 & 0.19 & 0.16 & 0.14 & 0.11 & 0.04 & 0.06 & 0.20 & 0.20 \\
\hline $\mathrm{MgO}$ & 29.85 & 25.73 & 24.47 & 26.29 & 27.28 & 23.73 & 25.45 & 24.4 & 11.37 & 16.51 & 15.36 & 18.29 \\
\hline $\mathrm{CaO}$ & 2.58 & 3.63 & 4.42 & 3.10 & 3.67 & 3.58 & 3.40 & 3.78 & 5.25 & 4.36 & 9.24 & 10.95 \\
\hline $\mathrm{Na}_{2} \mathrm{O}$ & 0.02 & 0.26 & 0.17 & 0.05 & 0.06 & 0.21 & 0.18 & 0.11 & 0.09 & 0.10 & 0.13 & 0.08 \\
\hline $\mathrm{K}_{2} \mathrm{O}$ & 0.77 & 0.81 & 0.59 & 0.55 & 0.73 & 0.89 & 1.21 & 0.86 & 2.02 & 2.58 & 0.52 & 0.50 \\
\hline $\mathrm{P}_{2} \mathrm{O}_{5}$ & 1.82 & 2.47 & 3.70 & 1.89 & 2.28 & 2.45 & 1.87 & 2.65 & 3.45 & 3.09 & 2.17 & 1.70 \\
\hline $\mathrm{H}_{2} \mathrm{O}^{+}$ & - & - & 8.62 & 9.62 & 9.79 & 9.67 & 9.33 & - & nd & 5.27 & 5.64 & 4.39 \\
\hline $\mathrm{H}_{2} \mathrm{O}^{-}$ & - & - & - & 5.15 & 4.22 & 4.99 & 3.37 & - & nd & 2.56 & 5.24 & - \\
\hline $\mathrm{CO}_{2}$ & - & - & - & 0.24 & 0.39 & 0.45 & 0.74 & - & nd & 0.29 & 8.27 & - \\
\hline $\mathrm{SO}_{3}$ & - & - & - & - & - & - & - & 1.66 & - & - & - & - \\
\hline $\mathrm{BaO}$ & - & - & - & - & - & - & - & 3.05 & - & - & - & - \\
\hline $\mathrm{Cr}_{2} \mathrm{O}_{3}$ & - & - & 0.25 & - & - & - & - & 0.17 & - & - & - & - \\
\hline $\mathrm{LOI}^{* *}$ & 10.32 & 11.84 & - & - & - & - & - & 8.12 & - & - & - & - \\
\hline Total & 99.96 & 98.82 & 95.09 & 99.77 & 99.46 & 99.26 & 99.74 & 98.90 & 88.29 & 100.0 & 100.06 & 101.90 \\
\hline C.I I $^{* * *}$ & 1.33 & 1.39 & 1.46 & 1.45 & 1.39 & 1.42 & 1.60 & 1.47 & 3.02 & 1.87 & 2.46 & 2.00 \\
\hline $\operatorname{Ilm} . \mathrm{I}^{* * * *}$ & 0.44 & 0.59 & 0.64 & 0.50 & 0.42 & 0.60 & 0.41 & 0.60 & 1.67 & 1.37 & 0.87 & 0.9 \\
\hline
\end{tabular}

Data sources: MJW from Chalapathi Rao (2005); M from Lehmann et al (2002); M/A = Average of 7 Majhgawan pipe samples from Soni et al (1987); MG6, MG50, UG11a, UG191,HV-1/3, HV-4/2 \& HV-4/6 from Paul et al (1975b); 7 from Gupta et al (1986); H \& G = Average of ten analyses from Halder and Ghosh (1981); H/1 from Soni et al (1987); $*=$ Total iron; $* *=$ Loss on ignition; $* * *=$ Contamination index (Clement 1982); $* * * *=$ Ilmenite index (Taylor et al 1994).

and Skinner 1984). Glassy ash material was also observed in the groundmass of the Hinota pipe (Scott-Smith 1989).

\section{- Other accessory phases}

Monazite and barite are present in both the pipes. Monazite is also known to occur in orangeites of southern Africa but is atypical of archetypal kimberlites and lamproites. Even though barite is uncommon in lamproites, many of the Australian lamproites do contain a relatively high proportion of it (E M W Skinner, Pers. Comm. 2003). Magnetite, magnesio-chromite and titanomagnetite constitute various spinel groups of minerals (Ravi Shanker et al 2002). Haematite, leucoxene, ilmenite, rutile, anatase and perovskite are the other various identified opaque mineral phases (Mathur and Singh 1971). A number of heavy minerals such as ilmenite, kyanite, epidote, clinozoisite, spinel, zircon, garnet and tourmaline have also been reported (Venkataraman 1960; Grantham 1964). Pyrite, chalcopyrite, sphalerite and pentlandite constitute the reported sulphide phases (Ravi Shanker et al 2002).

The petrographical and mineralogical aspects of the Majhgawan and Hinota pipes reveal that their utility in the nomenclature of the pipe rock is not straightforward. The complex morphology of olivine macrocrysts, the presence of glass and scoracious juvenile lapilli and titanium-rich phenocrystic phlogopites are indeed characteristic features of lamproites, as first suggested by Scott-Smith (1989). To date, vesicles and glass are common only in Forte a la Corne type kimberlites in Canada (E M W Skinner, Pers. Comm. 2003) and are not found in classical kimberlite of South Africa. However, primary carbonate is atypical of the lamproites (Hammond and Mitchell 2002). On the other hand, monazite and barite are reported from orangeites but uncommon in archetypal kimberlite or lamproite. Thus, it can be inferred that the petrography and mineralogy of the Majhgawan and Hinota pipes is more similar to that of a lamproite and to some extent that of an orangeite than that of an archetypal kimberlite.

\section{Geochemistry}

Most of the geochemical data that has been built up over the years on the Majhgawan and Hinota pipes predominantly concerns the major oxides (e.g., Paul et al 1975a; Halder and Ghosh 1981; Soni et al 1987; Rock and Paul 1989; Paul 1991). 


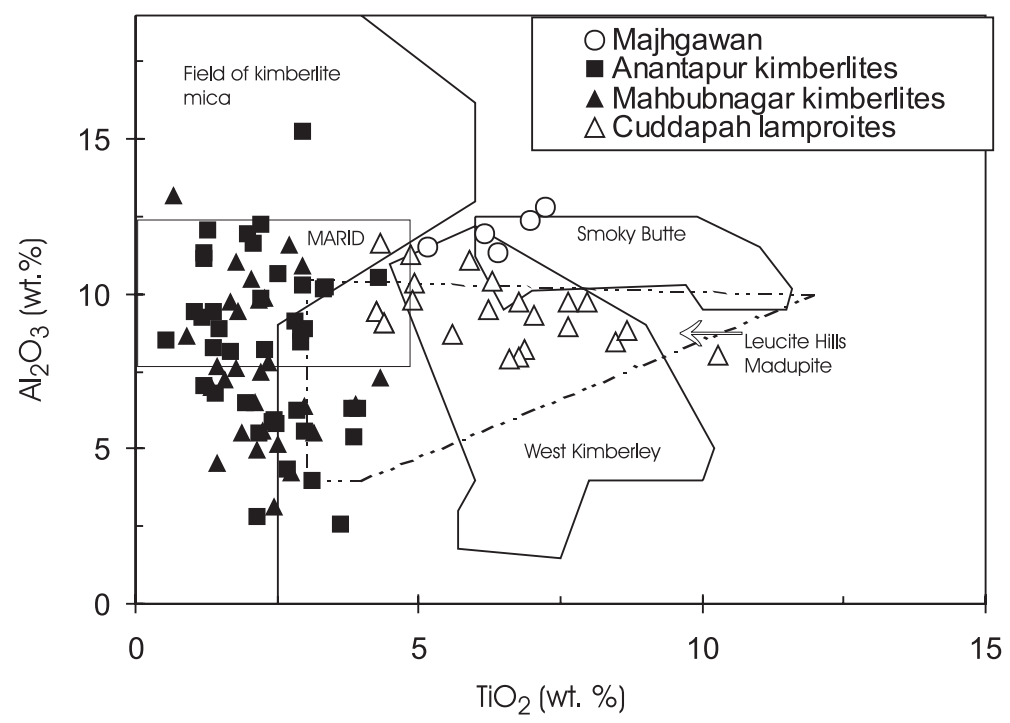

Figure 2. $\mathrm{TiO}_{2}\left(\mathrm{wt} \%\right.$ ) versus $\mathrm{Al}_{2} \mathrm{O}_{3}$ (wt\%) for micas from the Majhgawan pipe with those from other areas. Fields for selected Group I and II kimberlites, lamproites, and the MARID (Mica-amphibole-rutile-ilmenite-diopside) suite of xenoliths are from: Dawson and Smith (1977); Smith et al (1978); Scott-Smith et al (1989); Mitchell and Bergman (1991). The data for the Anantapur and Mahbubnagar kimberlites and the Cuddapah lamproites (India) are from Chalapathi Rao et al (2004).

The major oxide and trace element (including REE) data sets on the same samples are extremely few (Lehmann et al 2002; Chalapathi Rao 2005). The available major oxide and trace element data of the Majhgawan and Hinota pipes is provided in tables 4 and 5 respectively.

\subsection{Major element geochemistry}

As kimberlites, orangeites and lamproites incorporate varying proportions of crustal and mantle xenoliths on their rapid ascent from the mantle to the Earth's surface, the bulk composition of their magmas seldom approximates that of the original magma. The contamination index (C.I.) of Clement (1982) is widely used in kimberlite/lamproite petrology (Mitchell 1986; Taylor et al 1994; Beard et al 2000) to assess the role of crustal assimilation on the bulk chemistry of samples where C.I. $=\left(\mathrm{SiO}_{2}+\mathrm{Al}_{2} \mathrm{O}_{3}+\mathrm{Na}_{2} \mathrm{O}\right) /$ $\left(\mathrm{MgO}+\mathrm{K}_{2} \mathrm{O}\right)$. In altered and highly contaminated rocks, this index is of little use in assessing the role of crustal contamination. Kimberlites with a C.I. $<1.4$ are generally regarded as uncontaminated or fresh. The C.I. for a majority of the samples (table 4) of Majhgawan pipe is low and varies from 1.3 to 1.4. However, the highly altered nature of Hinota pipe (table 4; low $\mathrm{MgO}$ and high $\mathrm{Alu}-$ mina) results in its high C.I. (1.87-3.02).

The Ilmenite Index (Ilm. I) of Taylor et al (1994) is also used to identify kimberlites and lamproites that may have accumulated ilmenite megacrysts and xenocrysts. This index is defined as: $\mathrm{Ilm} \mathrm{I}=\left(\mathrm{FeO}_{\mathrm{T}}+\mathrm{TiO}_{2}\right) /\left(2 \mathrm{~K}_{2} \mathrm{O}+\mathrm{MgO}\right)$. Samples with Ilm. I $<0.52$ are regarded as uncontaminated. The Ilm. I for a majority of the Majhgawan pipe samples is either $<0.52$ or close to it whereas for the Hinota pipe it is $>0.87$ (table 4). The Ilm. I vs. C.I. plot (figure 3) clearly depicts the Majhagwan data predominantly plotting in the archetypal kimberlite (Group I) field or in its overlap with the lamproites. On the other hand, the Hinota samples, owing to their high combined C.I. and Ilm. I indices, plot slightly off the fields of uncontaminated kimberlites and lamproites.

The Majhagwan and Hinota pipes are silicaundersaturated $\quad\left(\mathrm{SiO}_{2} \quad\right.$ contents: $30.99 \mathrm{wt} \%$ $-37.94 \mathrm{wt} \%)$ similar to those of kimberlites, and orangeites (figure 3 ). Whereas the $\mathrm{CaO}$ contents are remarkably low (predominantly $2.58-3.78 \mathrm{wt} \%$; see table 4) for the Majhgawan pipe, those of Hinota are relatively high and reach up to $10.95 \mathrm{wt} \%$ (table 4). However, in terms of their silica and $\mathrm{CaO}$ contents both these pipes are similar to the archetypal kimberlites rather than orangeites and lamproites (figure 4). The $\mathrm{MgO}$ contents of Majhagwan pipe (23-29 wt\%) are high, compared to those of Hinota (11.37-18.29 wt\%). This is also duplicated in their total iron contents suggesting the highly altered (serpentinised) nature of the Hinota pipe. The $\mathrm{Mg}$ numbers $(\mathrm{Mg} / \mathrm{Mg}+\mathrm{Fe})$ of the Majhgawan $(>70)$ and Hinota $(>65)$ pipes are sufficiently high to signal their mafic-ultramafic nature. The $\mathrm{K}_{2} \mathrm{O}$ contents are low (0.50-1.21 wt\%), but the $\mathrm{K}_{2} \mathrm{O} / \mathrm{Na}_{2} \mathrm{O}$ ratios are high $(>3)$ thereby displaying the potassicultrapotassic nature (Foley et al 1987). However, two of the samples (see table 4) from the Hinota 
Table 5. Trace elements, including REE (in ppm) chemistry of Majhgawan and Hinota pipes.

\begin{tabular}{|c|c|c|c|c|c|c|c|c|c|c|}
\hline $\begin{array}{l}\text { Element } \\
(\mathrm{ppm})\end{array}$ & MJW & M & $\operatorname{Mg} 6$ & $\begin{array}{l}\text { Majhgawan } \\
\text { MG } 50\end{array}$ & UG 11a & UG 191 & 7 & $\mathrm{HV}-1 / 3$ & $\begin{array}{l}\text { Hinota } \\
\mathrm{HV}-4 / 2\end{array}$ & $\mathrm{HV}-4 / 6$ \\
\hline $\mathrm{Ba}$ & 1884 & 1734 & 7760 & 1640 & 7260 & 2400 & - & 2720 & 2980 & 680 \\
\hline $\mathrm{Cr}$ & 1456 & 996 & - & - & - & - & - & - & - & - \\
\hline Cs & 3.39 & - & - & - & - & - & - & - & - & - \\
\hline $\mathrm{Cu}$ & 44 & 52 & - & - & - & - & 42 & - & - & - \\
\hline $\mathrm{Hf}$ & 20.3 & 5.1 & 19.3 & 24.5 & 23.8 & 16.7 & - & 29.6 & 29.7 & 23.9 \\
\hline $\mathrm{Nb}$ & 177.3 & 228 & - & - & - & - & 214 & - & - & - \\
\hline $\mathrm{Ni}$ & 1455.9 & 1071 & - & - & - & - & 1059 & - & - & - \\
\hline $\mathrm{Pb}$ & 20.2 & 23.5 & - & - & - & - & 41 & - & - & - \\
\hline $\mathrm{Rb}$ & 39.4 & 56.3 & - & - & - & - & 76 & - & - & - \\
\hline $\mathrm{Sc}$ & 17.1 & 19 & - & - & - & - & 21 & - & - & - \\
\hline $\mathrm{Sr}$ & 1043.7 & 1694 & - & - & - & - & 1835 & - & - & - \\
\hline $\mathrm{Ta}$ & 11.67 & 16 & 13 & 15.5 & 16.8 & 10.1 & - & 14.9 & 15 & 11.4 \\
\hline Th & 12.8 & 16.2 & 12.8 & 16.8 & 16.1 & 17.6 & 15 & 19.9 & 11.4 & 15.5 \\
\hline $\mathrm{U}$ & 3.06 & 3.5 & - & - & - & - & - & - & - & - \\
\hline $\mathrm{V}$ & 52.8 & 33 & - & - & - & - & 55 & - & - & - \\
\hline $\mathrm{Y}$ & 15.57 & 26.5 & - & - & - & - & 35 & - & - & - \\
\hline $\mathrm{Zn}$ & 62 & 85 & - & - & - & - & 80 & - & - & - \\
\hline $\begin{array}{l}\mathrm{Zr} \\
R E E\end{array}$ & 754.7 & 973 & & & - & - & 1079 & - & - & - \\
\hline $\mathrm{La}$ & 186 & 239 & 156 & 188 & 179 & 161 & 410 & 71 & 139 & 192 \\
\hline $\mathrm{Ce}$ & 423.7 & 525 & 371.8 & 508.8 & 472.7 & 332.3 & 826 & 138.1 & 381.3 & 468.5 \\
\hline $\operatorname{Pr}$ & 50.73 & 66.6 & - & - & - & - & - & - & - & - \\
\hline $\mathrm{Nd}$ & 185.3 & 230 & 159 & 241.9 & 225.9 & 140.5 & 361 & 78.7 & 193.6 & 220.8 \\
\hline $\mathrm{Sm}$ & 24.9 & 29.3 & 22.5 & 31.9 & 33.3 & 22.2 & - & 24.2 & 39.7 & 32.2 \\
\hline $\mathrm{Eu}$ & 6.26 & 7.08 & 5 & 6.5 & 6.5 & 5.2 & - & 5.8 & 9.1 & 7.2 \\
\hline $\mathrm{Gd}$ & 20.23 & 16.4 & 8 & 16.8 & 17.8 & 9.8 & - & 11.1 & 17.6 & 14.6 \\
\hline $\mathrm{Tb}$ & 1.68 & 1.74 & 1.32 & 1.85 & 2.07 & 1.81 & - & 2.11 & 2.68 & 2.12 \\
\hline Dy & 5.09 & 7.41 & - & - & - & - & - & - & - & - \\
\hline Ho & 0.73 & 1.09 & - & - & - & - & - & - & - & - \\
\hline Er & 1.32 & 2.24 & - & - & - & - & - & - & - & - \\
\hline $\mathrm{Tm}$ & 0.16 & 0.24 & - & - & - & - & - & - & - & - \\
\hline $\mathrm{Yb}$ & 1 & 1.31 & 0.98 & 1.3 & 1.33 & 1.98 & - & 1.79 & 2.21 & 1.75 \\
\hline $\mathrm{Lu}$ & 0.1 & 0.21 & 0.11 & 0.12 & 0.13 & 0.29 & - & 0.01 & 0.24 & 0.24 \\
\hline$\Sigma \mathrm{REE}$ & 907.2 & 1127.62 & 724.71 & 997.17 & 938.73 & 675.08 & 1597 & 332.81 & 785.43 & 939.41 \\
\hline
\end{tabular}

Data Sources: MJW from Chalapathi Rao (2005); M from Lehmann et al (2002); MG6, MG50, UG11a, UG191, HV-1/3, HV-4/2 \& HV-4/6 from Paul et al (1975b); $7=$ Gupta et al (1986).

pipe (HV-1/3 and HV-4/2) display relatively high potash contents $(>2.02 \mathrm{wt} \%)$ probably owing to their high modal mica contents. $\mathrm{TiO}_{2}$ contents in both these pipes are very high (3.76-9.51 wt\%) due to a high modal rutile. $\mathrm{P}_{2} \mathrm{O}_{5}$ contents range from 1.82 to $3.70 \mathrm{wt} \%$ and are primarily contributed by apatite and to a very limited extent by monazite. The peralkaline $\left[\right.$ molar $\left(\mathrm{Na}_{2} \mathrm{O}+\mathrm{K}_{2} \mathrm{O}\right) / \mathrm{Al}_{2} \mathrm{O}_{3}$ ] and perpotassic (molar $\mathrm{K}_{2} \mathrm{O} / \mathrm{Al}_{2} \mathrm{O}_{3}$ ) indices of Majhagwan and Hinota pipes are essentially $<1$. These are similar to those of archetypal kimberlites $(\leq 1)$ but are very different from those $(>1)$ of orangeites (Mitchell 1995a) and lamproites (Mitchell and Bergman 1991).
The overall major element data of Majhagwan and Hinota pipes suggest that they are more similar to that of an archetypal kimberlite than those of orangeite and lamproite.

\subsection{Trace element geochemistry}

Widely varying macrocryst/phenocryst-matrix ratios are believed to be responsible for the variability of compatible element abundances in kimberlites and related rocks (Mitchell 1986). In kimberlites, Sc is primarily hosted by phlogopite whereas in lamproites by K-richterite (Mitchell 1995a). The Sc contents in the Majhgawan pipe 


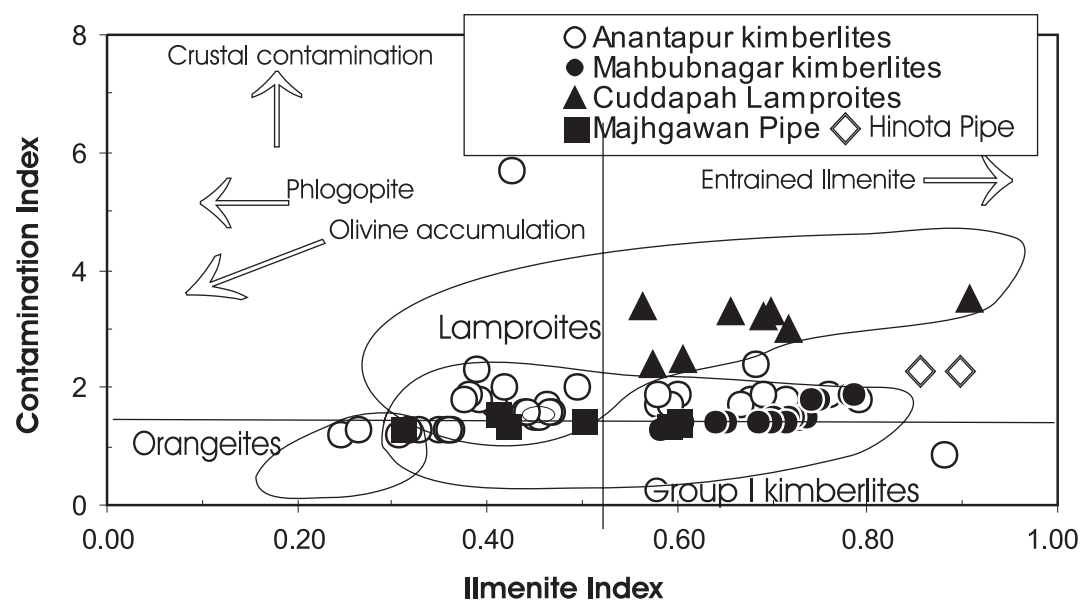

Figure 3. Contamination index (Clement 1982) versus Ilmenite index (Taylor et al 1994) for Majhgawan and Hinota pipes. The fields of world-wide lamproites, Group I and II kimberlites are shown for comparison. Data sources are as follows: Fraser (1987); Greenwood et al (1999); Gurney and Ebrahim (1973); Spriggs (1988); Scott (1979); Smith et al (1985); Tainton (1992); Taylor et al (1994).

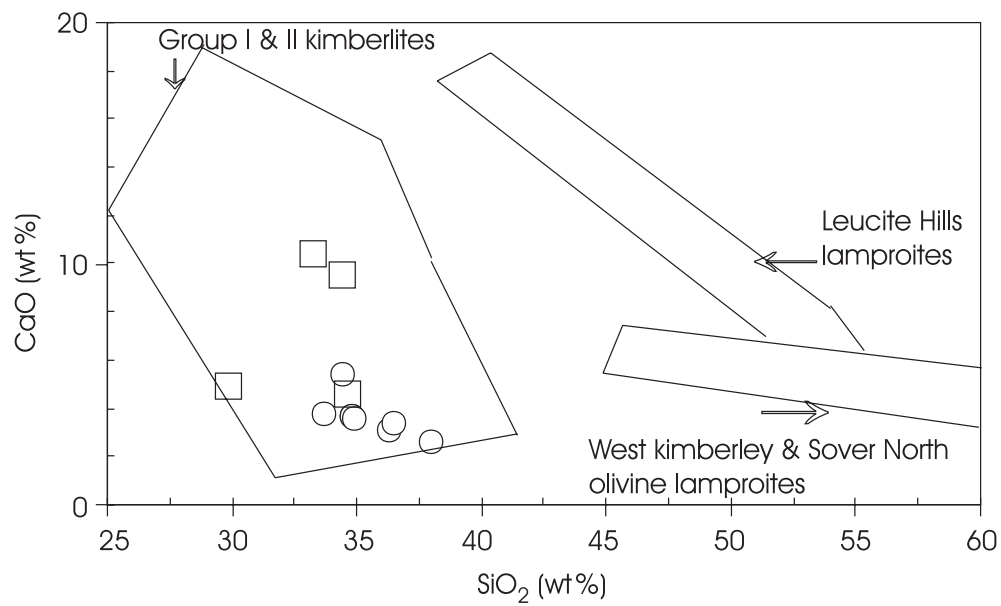

Figure 4. Compositional range of $\mathrm{SiO}_{2}(w \mathrm{t} \%)$ and $\mathrm{CaO}$ (wt\%) for the Majhgawan and Hinota pipes. Circles = data of the Majhgawan pipe; squares = data of the Hinota pipe. Data sources are as follows: West kimberley olivine lamproites and Leucite Hills lamproites - Fraser (1987); Group I and II kimberlites - Greenwood et al (1999); Gurney and Ebrahim (1973); Spriggs (1988); Scott (1979); Smith et al (1985); Tainton (1992); Taylor et al (1994); Chalapathi Rao et al (2004).

$(\sim 20 \mathrm{ppm})$ overlap with those from the southern Indian kimberlites (13-27 ppm) and lamproites ( 20 ppm) (Chalapathi Rao et al 2004). Vanadium in kimberlites and lamproites is hosted primarily in phlogopite and spinel. The Majhgawan pipe has relatively lower $\mathrm{V}$ abundances $(33-55 \mathrm{ppm})$, probably due to the relative paucity of their hosting phases, compared to the kimberlites (75-355 ppm) and lamproites $(72-160 \mathrm{ppm})$ from southern India (Chalapathi Rao et al 2004). $\mathrm{Ni}$ in kimberlites and lamproites is principally hosted by olivine and hence its abundance is directly proportional to the macrocryst olivine content. Cr (996-1456 ppm) contents in Majhgawan pipe are within the range for those in orangeites (315-2865 ppm), kimberlite (430-2554 ppm) as well as olivine lamproites (379-1703 ppm) (source data: Mitchell 1995a).
Unfortunately, no compatible trace element data are available in the literature for the Hinota pipe to make a comparison.

The barium contents of the Majhgawan pipe are extremely high (680-7760 ppm) (table 5) and reflects their high barite content. Scott-Smith and Skinner (1984) have used $\mathrm{Zr}$ versus Nb plots to distinguish between kimberlites and lamproites. These elements are also shown to be least mobile amongst incompatible elements whilst alteration (Taylor et al 1994). The $\mathrm{Nb}$ and $\mathrm{Zr}$ contents of Majhgawan pipe plot very well within the olivine lamproite field (figure 5). $\mathrm{Zr}$ and $\mathrm{Nb}$ data are not available for the Hinota pipe (table 5).

The Majhgawan and Hinota pipes are strongly enriched in LREE with La abundances being 500-800 $\times$ chondrite (figure 6). Abundances of 


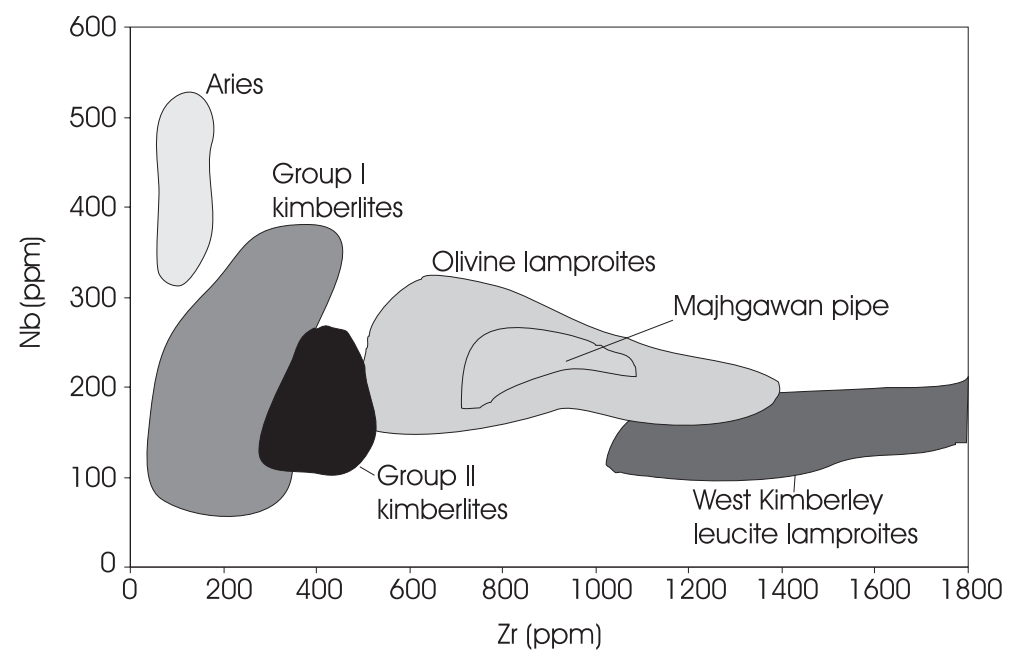

Figure 5. Zr versus Nb. Trace element (ppm) covariation diagram for the Majhgawan pipe. Data sources for the shown fields are from Edwards et al (1992) and Taylor et al (1994).

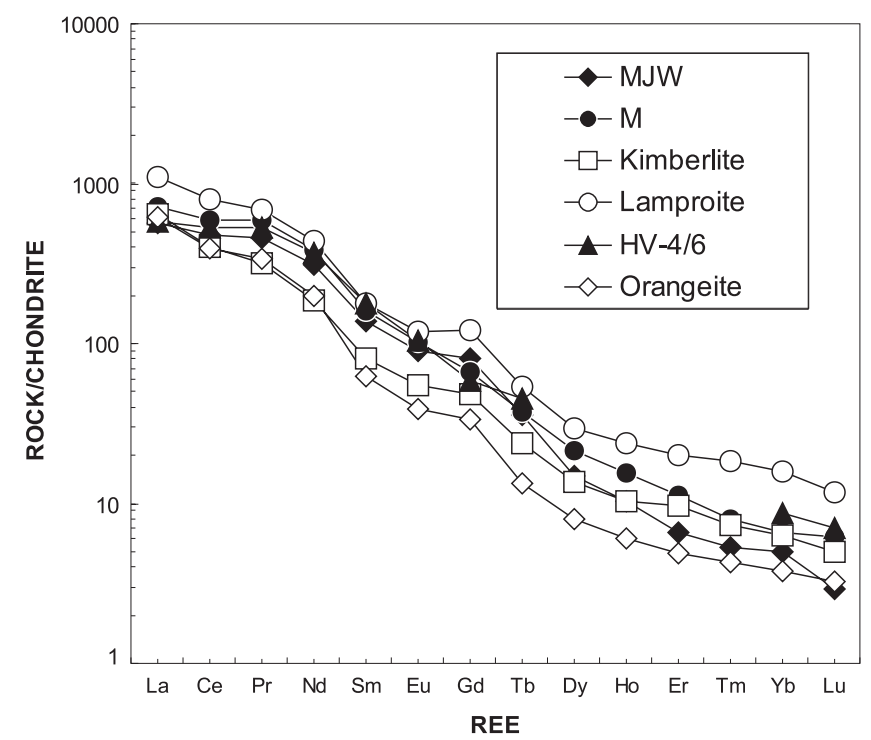

Figure 6. Chondrite-normalized (Haskin et al 1968). Rare Earth Element patterns for the Majhgawan and Hinota pipes compared with those from elsewhere. Data for kimberlite and lamproite is from Chalapathi Rao et al (2004); Orangeite from Mitchell (1995a).

HREE are relatively much low, 5-10 $\times$ chondrite. Consequently, $\mathrm{La} / \mathrm{Yb}$ ratios are high and range from 80-186. Even though, some of the HREE measurements are not available for the Hinota pipe (table 6), the latter's normalized REE profile is similar to that of Majhgawan. Both these pipes appear to be enriched in LREE (figure 6) compared to the archetypal kimberlite (e.g., Pipe-7, Anantapur district, Andhra Pradesh, India; data from Chalapathi Rao et al 2004) and orangeite (e.g., Newlands, South Africa; data from Mitchell 1995a) but relatively less enriched compared to that of the Chelima lamproite of southern India (data from
Chalapathi Rao et al 2004). Even though REE patterns cannot be used to distinguish kimberlites from orangeites (Mitchell 1995a) those of Majhgawan and Hinota pipes nevertheless parallel the patterns of archetypal kimberlite, lamproite and orangeite (figure 6) thereby demonstrating that similar processes were involved in the generation of their magma. The REE patterns (figure 6) also do not show any apparent depletion of MREE (Eu to Ho) and lack a downward concave shape which is a characteristic feature of some of the other Gondwanaland kimberlites, e.g., Aries kimberlite of western Australia (Edwards et al 1992) and Koidu kimberlite of west Africa (Taylor et al 1994).

From the steep REE patterns (figure 6) the source region of Majhgawan and Hinota pipes is inferred to have been derived from a relatively deeper part of the sub-continental lithospheric mantle source (continental roots or lithospheric keels) - within the garnet stability field - which has undergone an initial depletion event (extensive melting) which can be linked to an episode of continent formation (see Chalapathi Rao et al 2004). This is also supported by $\mathrm{Nd}$ isotope data (below). The initial depletion of the mantle source in the garnet stability region is imperative to account for the observed low concentrations of HREE in equilibrium with the melt since any subsequent metasomatic enrichment can only produce the observed LREE concentrations (see also Tainton and McKenzie 1994; Chalapathi Rao et al 2004). Most likely evidence for the initial depletion event comes from the extensive mafic-ultramafic volcanic units from the Bijawar and Mahakoshal supracrustal belts which are considered to underlie the Vindhyan sediments (e.g., Roy and Devarajan 2000; Roy and Hanuma Prasad 2001). 
Table 6. Initial ${ }^{87} \mathrm{Sr} /{ }^{86} \mathrm{Sr}$ and ${ }^{143} \mathrm{Nd} /{ }^{144} \mathrm{Nd}$ composition of Majhgawan and Hinota pipes. Errors in parentheses are 2 sigma and refer to last digits. Assumed age of emplacement for both the pipes is $1.1 \mathrm{Ga}$.

\begin{tabular}{|c|c|c|c|c|c|}
\hline Sample no. & $\mathrm{Rb}(\mathrm{ppm})$ & $\mathrm{Sr}(\mathrm{ppm})$ & ${ }^{87} \mathrm{Rb} /{ }^{86} \mathrm{Sr}$ & $\begin{array}{c}{ }^{87} \mathrm{Sr} /{ }^{86} \mathrm{Sr} \\
\text { (measured) }\end{array}$ & $\begin{array}{l}{ }^{87} \mathrm{Sr} /{ }^{86} \mathrm{Sr} \\
\text { (initial) }\end{array}$ \\
\hline \multicolumn{6}{|l|}{ Majhgawan } \\
\hline MG21 & 20.3 & 1206 & 0.049 & $0.7036(3)$ & 0.7028 \\
\hline MG50 & 43.1 & 1513 & 0.083 & $0.7044(1)$ & 0.7031 \\
\hline MG11 & 15.8 & 87.8 & 0.052 & $0.7045(6)$ & 0.7037 \\
\hline MG40 & 37.3 & 1343 & 0.080 & $0.7048(2)$ & 0.7035 \\
\hline MG6 & 36.3 & 1207 & 0.087 & $0.7050(3)$ & 0.7036 \\
\hline MG25 & 39.4 & 1343 & 0.085 & $0.7051(3)$ & 0.7038 \\
\hline UG11A & 81.1 & 1558 & 0.151 & $0.7066(5)$ & 0.7042 \\
\hline UG136 & 97.6 & 1577 & 0.179 & $0.7069(1)$ & 0.7041 \\
\hline UG84 & 60.0 & 1316 & 0.132 & $0.7073(2)$ & 0.7052 \\
\hline \multicolumn{6}{|l|}{ Hinota } \\
\hline $\mathrm{HV} 4 / 4$ & 99.1 & 1824 & 0.157 & $0.7063(1)$ & 0.7038 \\
\hline $\mathrm{HV} 4 / 7$ & 63.6 & 1047 & 0.176 & $0.7074(2)$ & 0.7046 \\
\hline $\mathrm{HV} 4 / 1$ & 29.8 & 605 & 0.143 & $0.7086(6)$ & 0.7063 \\
\hline $\mathrm{HV} 4 / 6$ & 37.0 & 628 & 0.171 & $0.7093(5)$ & 0.7066 \\
\hline $\begin{array}{l}\text { Sample no. } \\
\text { M (Majhgawan) }\end{array}$ & $\begin{array}{c}\text { Sm (ppm) } \\
26.73\end{array}$ & $\begin{array}{c}\mathrm{Nd}(\mathrm{ppm}) \\
230.8\end{array}$ & $\begin{array}{c}{ }^{147} \mathrm{Sm} /{ }^{144} \mathrm{Nd} \\
0.07007\end{array}$ & $\begin{array}{c}{ }^{143} \mathrm{Nd} /{ }^{144} \mathrm{Nd}(2 \sigma) \\
(\text { measured }) \\
0.511742 \pm 10\end{array}$ & $\begin{array}{c}{ }^{143} \mathrm{Nd} /{ }^{144} \mathrm{Nd} \\
\text { (initial) } \\
0.511236 \\
(\varepsilon \mathrm{Nd}=0.35)\end{array}$ \\
\hline
\end{tabular}

Data source: for Sr ratios - Paul (1979); for Nd ratio - Lehmann et al (2002).

On normalized multi-element plots (figure 7) Majhgawan and Hinota pipes exhibit negative troughs at $\mathrm{K}$ and also at $\mathrm{Rb}$. Such negative anomalies either reflect hydrothermal alteration or the presence of residual phases in the melt source regions. The LOI contents, which are similar to those from unaltered potassic-ultrapotassic rocks from elsewhere (Mitchell 1986), and low contamination indices (table 4) for the Majhgawan pipe suggest that these negative anomalies are likely to be source related. However, in the case of Hinota pipe both the petrography and contamination indices (see above) indicate undoubted effects of alteration. The possibility of phlogopite fractionation being responsible for the negative troughs at $\mathrm{K}$ and $\mathrm{Rb}$ is also negated by the lack of evidence for phlogopite accumulation (figure 3; see vector for phlogopite). Negative Rb and K anomalies were recorded in kimberlites and orangeites from southern Africa and ubiquitous trough at $\mathrm{K}$ is seen in many mafic potassic rocks from Alto Paranaiba Province, Brazil (Gibson et al 1995). Depletions at $\mathrm{P}$ and $\mathrm{Sr}$ are also apparent in figure 7. Negative troughs at $\mathrm{P}$ can be accounted for by the presence of residual apatite in the source. Depletions in $\mathrm{Sr}$ can be attributed either to the presence of residual phases such as clinopyroxene (Smith et al 1985) or phosphate (Mitchell 1995a) or due to the depletion of the mantle source in Sr during a previous phase melt extraction (Tainton and McKenzie 1994). The troughs at $\mathrm{Sr}$ were, in fact, considered by Foley et al (1987) to be a fairly common feature of mafic-ultramafic strongly alkaline rocks. Strong negative trough at Ti in the case of Hinota pipe suggests the presence of a residual Ti-enriched phase (rutile or Fe-Ti oxide) in the source.

\section{Isotope geochemistry}

The initial ${ }^{87} \mathrm{Sr} /{ }^{86} \mathrm{Sr}$ ratios for the Majhgawan pipe (for $t=1.1 \mathrm{Ga}$ ) range from 0.7028 to 0.7052 whereas the initial Nd ratio determined on a single sample gives a value of 0.511236 (measured ratio is 0.511742 ) (table 6). The initial ${ }^{87} \mathrm{Sr} /{ }^{86} \mathrm{Sr}$ of Hinota pipe range from 0.7038 to 0.7066 (table 6) and is indistinguishable from that of the Majhagwan. In the standard initial Sr versus $\varepsilon$ Nd plot (figure 8), the Majhgawan pipe plots in the kimberlite field.

The southern African Group I kimberlites have significantly lower ${ }^{87} \mathrm{Sr} /{ }^{86} \mathrm{Sr}$ and $\mathrm{Rb} / \mathrm{Sr}$ ratios and higher ${ }^{143} \mathrm{Nd} /{ }^{144} \mathrm{Nd}$ and ${ }^{206} \mathrm{~Pb} /{ }^{204} \mathrm{~Pb}$ ratios than Group II kimberlites (orangeites). In the $\mathrm{Nd}-\mathrm{Sr}$ isotope space (figure 8) the southern African Group I kimberlites are characterized by possessing a BulkSilicate Earth (BSE) like Sr isotopic composition and predominantly positive $\varepsilon \mathrm{Nd}$ values ranging from +0.3 to +6.9 that plot them in the 'depleted' quadrant of the conventional $\varepsilon \mathrm{Nd}-\mathrm{Sr}_{\mathrm{i}}$ diagram. The long term incompatible element enrichments relative to that of Bulk-Silicate Earth of Group II kimberlites (orangeites) make their field distinct from those of Group I kimberlites (figure 8). 


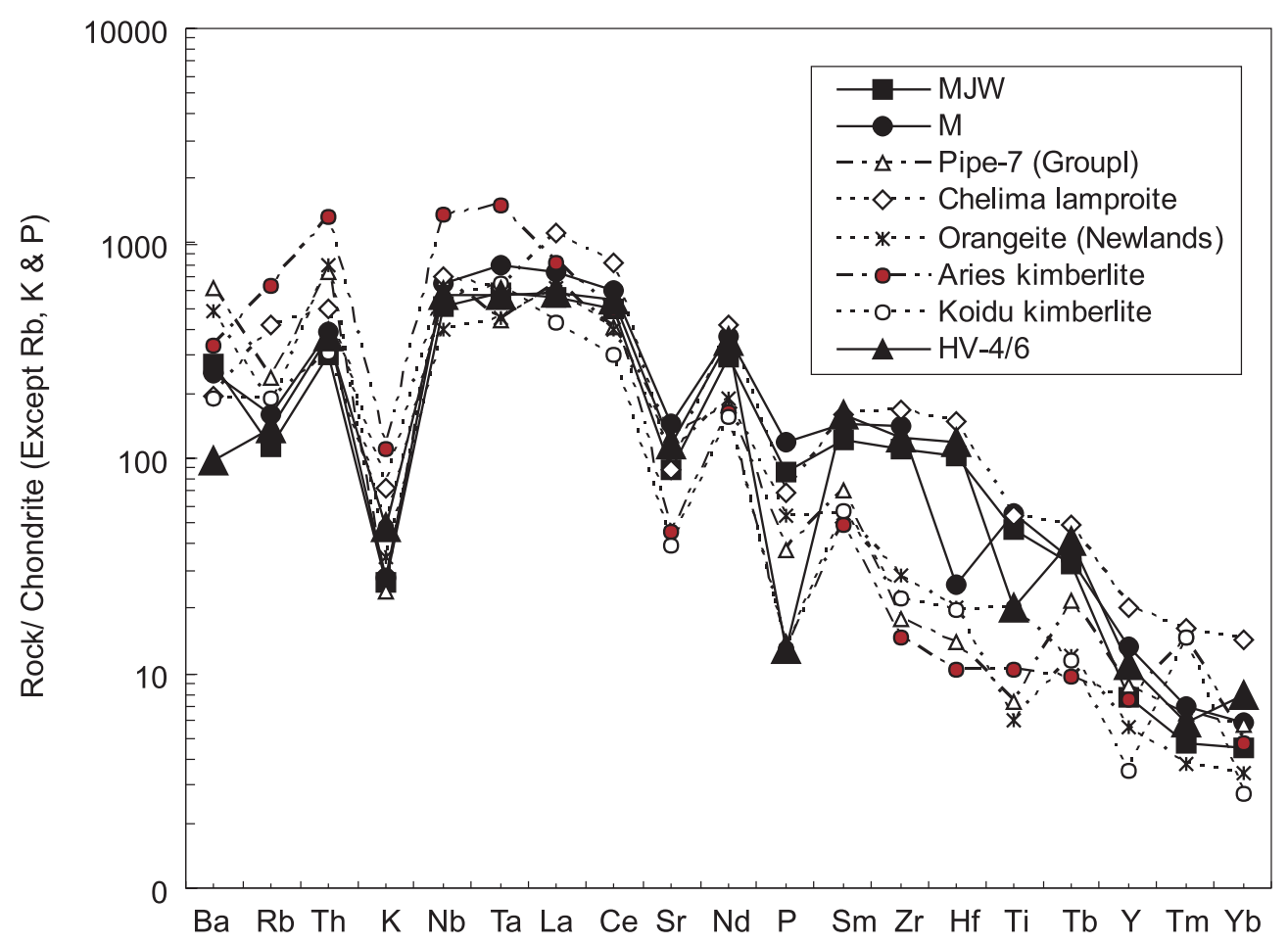

Figure 7. Trace element abundance patterns normalized against chondrite (except Rb, K and $\mathrm{P}$, which are normalized to primitive mantle; Thompson et al 1984) of the Majhgawan and Hinota pipes compared with those from elsewhere. Note that in case of Hinota pipe the values for Rb, Nb, Sr, Zr, Y and Tm are adopted from those of Majhgawan pipe. Data sources are from Mitchell (1995a); Edwards et al (1992); Taylor et al (1994); Chalapathi Rao (2005) and Chalapathi Rao et al (2004).

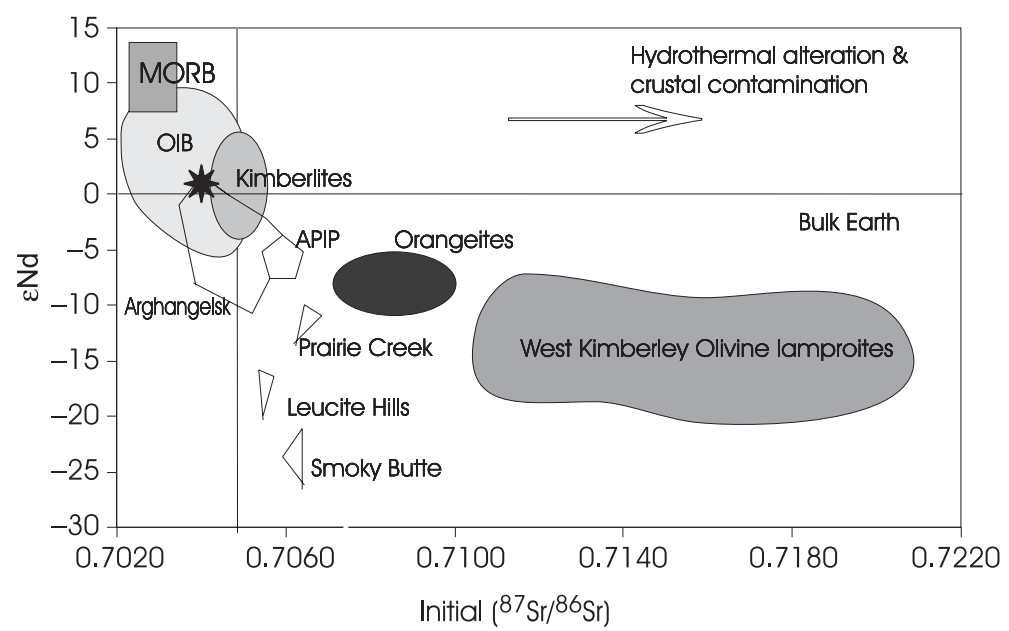

Figure 8. Initial ${ }^{87} \mathrm{Sr} /{ }^{86} \mathrm{Sr}$ versus $\varepsilon \mathrm{Nd}$ for the kimberlites, lamproites and orangeites. Data sources are Gibson et al (1995); Mahotkin et al (2000) and Chalapathi Rao et al (2004). The asterick shows the position of the Majhgawan pipe.

Group II kimberlites have unradiogenic $\mathrm{Nd}(\varepsilon \mathrm{Nd}$ -6.2 to -13.5$)$ and radiogenic Sr isotope composition (0.70713 to 0.70983$)$, which plots them in the 'enriched' quadrant of the $\varepsilon \mathrm{Nd}-\mathrm{Sr}_{\mathrm{i}}$ isotope diagram.

The term 'transitional kimberlite' was first introduced by Skinner et al (1994) on the basis of the intermediate $\mathrm{Sr}-\mathrm{Nd}$ isotopic characteristics of some of the kimberlites of the Prieska district of South Africa (Clarke et al 1991). Subsequently, such 'kimberlites' have been recognized from the other cratons as well such as those at Arkhangelsk, Russia (e.g., Mahotkin et al 2000; Beard et al 2000), Alto Paranaiba, Brazil (e.g., Bizzi et al 1994; Gibson et al 1995), Guaniamo, Venezuela (Kaminsky et al 2004) and from the North West 
Territories of Canada (Dowall et al 2000) (figure 8). In one of the first isotopic studies on lamproites, McCulloch et al (1983) have shown that the diamondiferous lamproites from the Fitzroy Trough of Western Australia have low $\varepsilon \mathrm{Nd}(-7.4$ to -15.4$)$ and high ${ }^{87} \mathrm{Sr} /{ }^{86} \mathrm{Sr}_{\mathrm{i}} 0.7104$ to 0.7187 indicating their derivation from ancient $(>1 \mathrm{Ga})$, enriched (high $\mathrm{Rb} / \mathrm{Sr}, \mathrm{Nd} / \mathrm{Sm}$ ) mantle sources. Most of the models on lamproite genesis propose that the unusual isotopic characteristics of lamproites require their sources evolved in isolation (Fraser et al 1985; Mitchell and Bergman 1991).

The initial $\varepsilon N d$ value of +0.35 (for $t=1.1 \mathrm{Ga}$ ) for the Majhgawan pipe can be interpreted as resulting from a relatively undifferentiated chondritic mantle source (Lehmann et al 2002; Basu and Tatsumoto 1979) or a source with slight time integrated depletion of light rare earth elements (e.g., Kramers et al 1981; Smith 1983). Thus, the initial ${ }^{87} \mathrm{Sr} /{ }^{86} \mathrm{Sr}$ and ${ }^{143} \mathrm{Nd} /{ }^{144} \mathrm{Nd}$ isotopic compositions of the Majhgawan pipe (figure 8) have been inferred to be similar those of archetypal kimberlites (and some of the 'transitional kimberlites') but are clearly atypical of lamproites or orangeites.

\section{Xenoliths and diamonds}

Juvenile lapilli or magmaclasts constitute cognate xenoliths whereas broken inclusions of Vindhyan rocks viz., argillaceous limestone, black cherty and greenish grey shale and quartz-arenite are prevalent throughout the pipes (Halder and Ghosh 1978; Soni et al 1987). Xenocrysts include predominantly Cr-rich pyrope garnets (up to $13 \mathrm{wt} \% \mathrm{Cr}_{2} \mathrm{O}_{3}$ ) as well as sub-calcic garnets in minor amounts (Chatterjee and Rao 1995; Scott-Smith 1992). G1, G2, G9, G10 and G11 varieties of garnets are also recognized from those collected from the tailing dumps (Mukherjee et al 1997). No mantle xenoliths are reported from either of these ultramafic pipes or their rarity has been explained as due to long residence time in the upper mantle and slow travel time on the basis of resorption phenomena observed in the phlogopite and olivine (serpentinised) megacrysts (Mukherjee et al op cit). The paucity of mantle xenoliths in the Majhgawan and Hinota pipes precludes direct information about the petrological nature of the sub-continental mantle beneath the Bundelkhand craton.

Whilst the Hinota pipe is considered subeconomic in terms of the diamond potential, the Majhgawan pipe is the only diamondiferous body presently mined on a commercial scale in India with an annual production of about 40,000 carats. The diamond incidence in the latter varies between 3 and 25 carats/ 100 tonnes with an average of 10 to
12 carats/100 tonnes (Ghosh 2002). The diamonds recovered are of very high quality with $42 \%$ of them being gem quality, which is amongst the highest in the world for rough diamonds. The form of the Majhgawan diamonds is mostly a combination of octohedron and dodecahedron; a large variety of them are predominantly curve-faced modified forms indicating signs of resorption (Chatterjee and Rao 1995). The diamond content of the Majhgawan pipe is indistinguishable from that in diamondiferous archetypal kimberlites, orangeites and lamproites and transitional kimberlites.

\section{Petrogenesis}

It is now well known that the geochemistry of the mafic potassic-ultrapotassic magmas can be utilized to investigate the relative contribution of lithosphere, upper- and deeper-mantle (convective) components in their genesis and also to probe compositional variations in the continental lithospheric mantle (e.g., Gibson et al 1995; Mahotkin et al 2000; Beard et al 1998, 2000). However, it is imperative to assess the role of the crustal contamination in order to constrain the genesis of Majhgawan and Hinota pipes.

\subsection{Role of crustal contamination}

Evidence against crustal contamination and argument for a mantle derivation of the Majhgawan pipe is supported by the high abundances of incompatible trace elements such as Sr (1043-1835 ppm), Nb (177-228 ppm) and $\mathrm{Zr}$ $(755-1075 \mathrm{ppm})$ which are much greater than in the continental crust. All the analysed rocks have molar $\mathrm{Mg} /(\mathrm{Mg}+\mathrm{Fe})$ ratios $>0.70$ and high Ni contents $(1055-1455 \mathrm{ppm})$ which are indicative of their 'primitive' nature of the magma. Moreover, the major oxide composition of the pipe rock reveal low abundances of $\mathrm{Al}_{2} \mathrm{O}_{3}(2.53-6.07 \mathrm{wt} \%)$ and $\mathrm{Na}_{2} \mathrm{O}$ $(0.02-0.26 \mathrm{wt} \%)$ that cannot be accounted for by crustal contamination. The presence of diamond and xenocrysts also support its mantle derivation. The contamination indices (see above) and major oxide composition $\left(\mathrm{Al}_{2} \mathrm{O}_{3}: 3.14-5.16 \mathrm{wt} \%\right.$; $\mathrm{CaO}: 4.36-10.95 \mathrm{wt} \%$ and high total iron contents) suggests that the samples from Hinota pipe were subjected to hydrothermal alteration. However, extremely low $\mathrm{Na}_{2} \mathrm{O}$ contents $(<0.13 \mathrm{wt} \%)$ and high $\mathrm{Mg} /(\mathrm{Mg}+\mathrm{Fe})$ ratios $(>0.65)$ point out that crustal contamination has little influence on the major element chemistry. Moreover, the presence of diamond is undoubtedly indicative of the mantle derivation of the magma.

The geochemical data on the Vindhyan sediments (e.g., Lower Vindhyan shales; Raza et al 


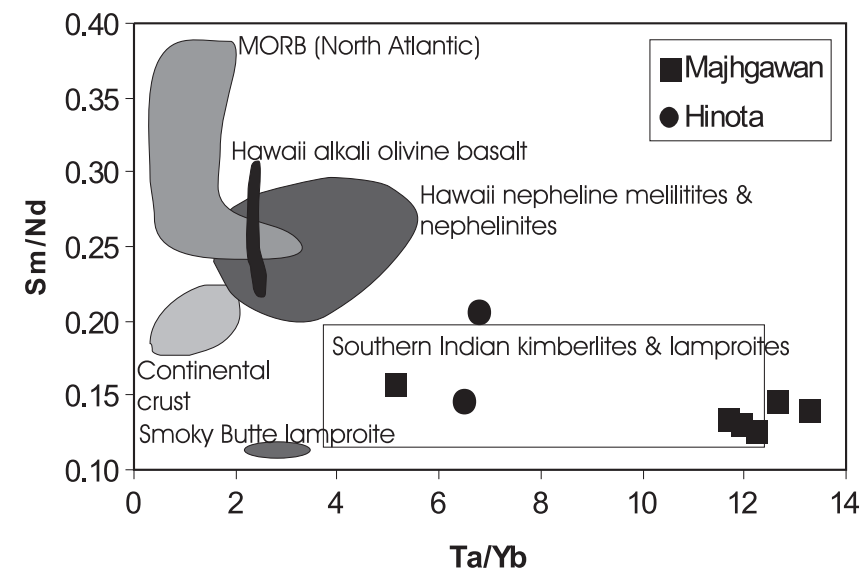

Figure 9. $\mathrm{Ta} / \mathrm{Yb}$ versus $\mathrm{Sm} / \mathrm{Nd}$ plot for the Majhgawan and Hinota pipes. The field of southern Indian kimberlites and lamproites is from Chalapathi Rao et al (2004). The other fields are adopted from Fraser et al (1985).

2002) suggests that they have relatively much lower $\mathrm{Zr}$ (60-406 ppm), Nb (11-63 ppm), Sr (9-163 ppm) and $\mathrm{Ni}(10-138 \mathrm{ppm})$ which cannot account for the relatively much higher values of these elements in the Majhgawan pipe. The strongly LREE-enriched REE patterns (500-800 $\times$ chondrite), absence of positive Eu anomalies and the low HREE and Y contents of the Majhagwan and Hinota pipe rocks provide further additional evidence against crustal contamination. The $\mathrm{Ta} / \mathrm{Yb}$ ratios of the Majhgawan and Hinota pipe rock samples are very high and their respective $\mathrm{Sm} / \mathrm{Nd}$ values are too low to have resulted from interaction between MORB and continental crust (figure 9). Thus, it can be concluded that the major oxide, trace element and isotopic signatures of the samples under study are not affected significantly by crustal contamination but reflects those of their source regions.

\subsection{Characteristics of the mantle source}

In the absence of reported mantle xenoliths from the Majhgawan and Hinota pipes, virtually no information is available regarding the nature of the mantle beneath this part of the Vindhyan basin and the Bundelkhand craton. Nevertheless, the following inferences can be drawn from the petrological and geochemical observations so as to constrain their petrogenesis:

- As these pipes are diamondiferous, the Proterozoic geothermal gradient beneath Bundelkhand craton must have passed through the diamond stability field. Therefore, the source magma should have originated at a depth of at least $150 \mathrm{~km}$.
- The high $\mathrm{TiO}_{2}$ contents of the phenocrystic and macrocrystic phlogopites could reflect the high titanium content of the parent magmas (e.g., Bachinskii and Simpson 1984).

- High Ba contents (presence of widespread barite) also indicate that the source was significantly enriched in barium. This barium was possibly contributed either by a Ba-rich phlogopite occurring as stockworks within the mantle source (Foley 1992) or by a complex K-Ba phosphatic metasomatic mineral phase, recognized in the 7 Gpa (40-70 kbar) near-solidus experimental studies of lamproites (Mitchell 1995b).

- From the normalized multi-element plots (figure 7) it has been inferred (see above) that phlogopite and clinopyroxene were the residual phases in the melt sources.

- The pipe rocks are strongly LREE enriched and significantly depleted in HREE (figure 6). It is now well established that such melts with high $\mathrm{La} / \mathrm{Yb}$ ratios (60-180) can be produced by very small $(<1 \%)$ degrees of partial melting of a phlogopite-garnet lherzolite (e.g., Mitchell and Bergman 1991).

- Furthermore, to generate such melts with high incompatible trace element and LREE abundances it is also well known that such a mantle source must have been previously metasomatically enriched (e.g., Menzies and Wass 1983).

- Multi-element plots (figure 7) do not show any subduction-related characteristics, such as large negative anomalies at $\mathrm{Ta}$ and $\mathrm{Nb}$ (e.g., Peacock 1990; Maury et al 1992), and therefore, the source enrichment is attributed to volatile and K-rich, extremely low-viscosity melts that leak continuously to semi-continuously from the asthenosphere and accumulate in the overlying lithosphere (e.g., Bailey 1982; McKenzie 1989; Wilson et al 1995) rather than by subductionderived melts (e.g., Murphy et al 2002).

- There is no evidence from the available data to decide whether the composition of the metasomatising melt could be strictly silicic (e.g., Watson et al 1990) or carbonate (e.g., Dobson et al 1996) or both.

- The epsilon $\mathrm{Nd}_{\mathrm{i}}$ value for the Majhgawan pipe can be interpreted as resulting from a relatively undifferentiated chondritic mantle source (Lehmann et al 2002) or a source with very slight time integrated depletion of light rare earth elements (e.g., Smith 1983).

- The Sr and Nd systematics of Majhgawan pipe also reveal that it has archetypal kimberlite like isotope signature and that its source region has not experienced ancient enrichment event(s) that are characteristic of orangeite or lamproite mantle sources. 


\subsection{Depth of melting: Lithosphere vs asthenosphere}

Despite a great deal of research, the role of the convecting mantle in kimberlite genesis is a highly contentious issue. The slightly depleted source region of Group I kimberlites, relative to BSE, was widely suggested as an evidence for their asthenospheric origin as their isotopic signatures are similar to those of most Ocean Island Basalts (e.g., Smith 1983; Mitchell 1995a). The presence of syngenetic inclusions of majoritic garnets within diamonds (Moore et al 1991) and ultra-deep (> $400 \mathrm{~km}$ ) xenoliths in some southern African kimberlites with ocean-island basalt (OIB)-like isotopic signature, i.e., Group I kimberlites, led some workers to suggest that they were derived from a 'transition zone' source (e.g., Ringwood et al 1992) or even from the core-mantle boundary (e.g., Haggerty 1994, 1999). Broad similarities in major elemental compositions and trace element abundance patterns between Group I and II kimberlites (orangeites) led Skinner (1989) to suggest that both of them may have been generated from different domains of the continental lithospheric mantle with volatile input from the asthenosphere. Recent Hf isotope systematic study on southern African kimberlites and orangeites has favoured a sub-lithospheric (convecting) mantle source (Nowell et al 2004).

Tainton and McKenzie (1994) have proposed that the REE patterns of the Group I and II kimberlites and lamproites require a three stage melting model involving (i) lithospheric peridotite source depleted by melt extraction of $\sim 20 \%$ in the garnet stability field, (ii) metasomatic enrichment by a MORB type melt and (iii) small fraction melting of this 'barren' harzburgitic source. Thus, the REE modelling of Tainton and McKenzie (1994) deduced that the kimberlite components derived from a convecting mantle (the precursor small-fraction highly metasomatised MORB type melts) were extracted from a depleted continental lithospheric mantle. Similar results were obtained from the REE modelling studies on Proterozoic archetypal kimberlites and lamproites of southern India (Chalapathi Rao et al 2004).

The role of (i) depleted lithospheric peridotite (e.g., high $\mathrm{Mg} \#$, high $\mathrm{Ni}$, low HREE), (ii) enrichment (e.g., high LREE, high incompatible trace elemental abundances) of this already depleted source by metasomatising fluids from sub-lithospheric source region and (iii) subsequent small-fraction melting are evident in the genesis of the Majhgawan and Hinota pipes, as concluded by many workers for potassic-ultrapotassic rock types elsewhere (e.g., Tainton and McKenzie 1994; Le Roex et al 2003; Chalapathi Rao et al 2004).

\section{Discussion}

This study demonstrates that the Majhgawan and Hinota pipes are not typical (sensu stricto) kimberlite or lamproite or orangeite, as suggested elsewhere (e.g., Paul 1991; Scott-Smith 1989; Ravi Shanker et al 2001, 2002), but constitute a transitional mafic potassic-ultrapotassic rock type which combines the characteristics of all three rock types. Such transitional rocks have also been recorded in almost every craton with their emplacement age ranging from Proterozoic to Mesozoic thereby implying their universal occurrence in space as well as time (see Chalapathi Rao 2005 for details). A recent observation by Haggerty and Birckett (2004) that there are "neither archetypal kimberlites nor ideal lamproites" in India also becomes significant in this context.

The I.U.G.S. sub-commission on the Systematics of Igneous Rocks (Woolley et al 1996) has endorsed the view, mainly on the basis of petrological grounds, that kimberlite, lamproite and orangeite constitute separate rock types. However the recommendations of the I.U.G.S. are inadequate, as shown in this work, when dealing with the nomenclature of transitional mafic potassic ultrapotassic rock types. For such rocks the name majhgawanite has been proposed by Chalapathi Rao (2005) - who has taken into consideration the antiquity of the Majhgawan pipe, its intriguing petrological, geochemical and isotope characteristics and also the legacy of India of introducing diamond to the world. This also would serve to distinguish them from typical kimberlite or lamproite or orangeite.

As a primary source, the Majhgawan pipe and its satellite body at Hinota are grossly inadequate to account for the widespread occurrence of diamonds in the Panna belt (Soni et al 2002). However, the discovery of alternate primary sources in the area has eluded the Geological Survey of India so far despite their extensive geophysical and geochemical surveys spanning decades (Mitra 1996). Hitherto undiscovered pipe rocks of 'transitional' nature in the Panna area (within the Vindhyan basin) being responsible for the previous unsuccessful geochemical/geophysical exploration are possible (see also Chalapathi Rao 2005). As it is well established worldwide that diamondiferous pipes occur in clusters, there is a strong possibility of the presence of a number of hidden pipes in the Panna diamond belt.

The basic requirement for the mantle to melt and generate magma is that the mantle temperature should exceed its solidus at any given pressure. Mantle melting takes place if the equilibrium conditions are changed, either by increasing its potential temperature (e.g., plume) or by a decrease of 
pressure (e.g., rifting), so as to change the temperature of the solidus. On these lines, the eruption of ultramafic potassic-ultrapotassic magmas within continental plates is often attributed to either continental extension caused by the stretching of the lithosphere and consequent decompressional melting and asthenospheric upwelling (e.g., Gibson et al 1995; Chalapathi Rao et al 2004) or to heat imparted by a mantle plume (e.g., England and Houseman 1984; Gibson et al 1995).

The initiation and subsidence of sedimentary basins are known to be primarily controlled by thermal factors on the scale of the lithosphere (McKenzie 1978). Intra-cratonic basins are thought to reflect crustal thinning and subsidence related to isostatic doming and erosion above lithospheric anomalies followed by thermal relaxation (Bickle and Eriksson 1982). The lack of any extensive igneous activity in the Vindhyan sediments (above), argues against extensive mantle melting and does not favour a plume as the cause of the genesis of the Majhgawan and Hinota pipes. The deposition of sediments of varying thickness in different stratigraphic Groups in a huge time span of $\sim 1000$ Ma suggests that extension undoubtedly played a role in the evolution of the Vindhyan basin. Moreover, comprehensive sedimentalogical studies carried out over the years strongly favour the formation of the Vindhyan basin largely through rift-controlled subsidence under an extensional regime (Bhattacharya 1996 and the references therein). Evidence for the extension and consequent crustal stretching of the Vindhyan crust is provided by gravity and magnetic data which suggest crustal thinning along the NagaurJhalawar geotransect (Bhilwara-Vindhyan contact in Rajasthan) (Mishra et al 1995). Occurrences of tholeiitic and basaltic flows (Khairmalia basalts) along with the lapilli-bearing volcaniclastics, that are reported from the base of the lower Vindhyan SuperGroup in Rajasthan, are also indicative of crustal thinning and rifting that have preceded basin formation (see Prasad 1984; Raza et al 2001). Therefore, it appears that crustal extension, rather than decompression melting induced by a plume, was responsible for the melting of the Majhgawan and Hinota pipes source region.

\section{Conclusions}

- The Mesoproterozoic diamondiferous ultramafic pipes at Majhgawan and Hinota, which intrude the Kaimur Group of Vindhyan rocks, combine the petrological, geochemical and isotope characteristics of kimberlite, orangeite (Group II kimberlite) and lamproite and hence are characterized as belonging to 'transitional kimberliteorangeite-lamproite' rock type. The name majhgwanite (Chalapathi Rao 2005) is proposed to distinguish them from other primary diamond source rocks.

- Petrological evidence suggests that the source regions of these pipes were enriched in titanium and barium. Geochemical evidence points out phlogopite, apatite and clinopyroxene to be the residual phases in the melt sources.

- The parent magma of Majhgawan and Hinota pipes is envisaged to have been derived by very small $(<1 \%)$ degrees of partial melting of a phlogopite-garnet lherzolite source which previously underwent a depletion (extensive melting) episode during the continent formation and experienced subsequent metasomatism (enrichment).

- There is no evidence of any subduction-related characteristics from the multi-element plots, such as large negative anomalies at $\mathrm{Ta}$ and $\mathrm{Nb}$, and therefore, the source enrichment is attributed to volatile and K-rich, extremely low-viscosity melts that leak continuously to semi-continuously from the asthenosphere and accumulate in the overlying lithosphere (e.g., Bailey 1982; McKenzie 1989) rather than by subduction-derived melts (e.g., Murphy et al 2002).

- The $\varepsilon \mathrm{Nd}_{\mathrm{i}}$ values for the Majhgawan pipe can be interpreted as resulting from a relatively undifferentiated chondritic mantle source (Lehmann et al 2002) or a source with very slight time integrated depletion of light rare earth elements (e.g., Kramers et al 1981).

- The Sr and Nd systematics of Majhgawan pipe also reveal that it has archetypal kimberlite like isotope signature and that its source region has not experienced ancient enrichment event(s) that are characteristic of orangeite or lamproite mantle sources.

- Extension, rather than decompression melting in a mantle plume, seems to have been responsible for the melting of the source regions of Majhgawan and Hinota pipes.

\section{Acknowledgements}

I thank Jyotiranjan S Ray for his invitation to contribute to this special volume on Vindhyan Geology. This work constitutes a part of my study of Indian kimberlites and lamproites carried out when I was a Cambridge-Nehru Scholar at the Department of Earth Sciences, University of Cambridge, UK during 1993-1997. I am grateful to Sally Gibson, Dave Pyle and Dan McKenzie for their help and inspiration during my stay at Cambridge. Incisive reviews by Dalim K Paul (Kolkata) 
and Hetu C Sheth (Mumbai) and editorial suggestions by Jyotiranjan S Ray have greatly improved the presentation of this paper. The views expressed in this paper are essentially those of the author only and not of the organization where he presently works.

\section{References}

Ahmed F 1971 Geology of the Vindhyan system in the eastern part of the Son Valley, Mirzapur District, U.P; Rec. Geol. Sur. India 96(2) 14.

Anil Kumar, Padmakumari V M, Dayal A M, Murthy D S N and Gopalan K 1993 Rb-Sr ages of Proterozoic kimberlites of India: evidence for contemporaneous emplacement; Precamb. Res. 62 227-232.

Anil Kumar, Gopalan K and Rajagopalan G 2001b Age of the Lower Vindhyan sediments, Central India; Curr. Sci. 81 806-809.

Auden J B 1933 Vindhyan sedimentation in Son Valley; Geol. Surv. India Memoir 62(2) 141-250.

Bachinskii S W and Simpson E L 1984 Ti-phlogopites of the Core minette: a comparison with the micas of other lamprophyres, potassic rocks, kimberlites and mantle xenoliths; Amer. Mineral. 69 41-51.

Bailey D K 1982 Mantle metasomatism - continuing chemical change within the earth; Nature 296 525-430.

Banerjee I 1964 On some broader aspects of Vindhyan sedimentation; Proc. 22nd Int. Geol. Congr. New Delhi, Sec 15 189-200.

Basu A R and Tatsumoto M 1979 Sm-Nd systematics in kimberlites and in the minerals of garnet-lherzolite inclusions; Science 205 398-401.

Beard A D, Downes H, Hegner E, Sablukov S M, Vetrin V R and Balogh K 1998 Mineralogy and geochemistry of Devonian ultramafic minor intrusions of the southern Kola peninsula, Russia: implication for the petrogenesis of kimberlites and melilites; Contrib. Mineral. Petrol. 130 288-303.

Beard A D, Downes H, Hegner E, Sablukov S M 2000 Geochemistry and mineralogy of kimberlites from the Arkhangelsk region, NW Russia: evidence for transitional kimberlite magma types; Lithos 51 47-73.

Bergman S C 1987 Lamproites and other K-rich igneous rocks: review of their occurrence, mineralogy and geochemistry; Geol. Soc. London Spec. Publ. 30 103-190.

Bhattacharya A 1996 (Ed) Recent Advances in Vindhyan Geology; Geol. Soc. India Memoir 36331.

Bickle M J and Eriksson K A 1982 Evolution and subsidence of early Precambrian sedimentary basins; Phil. Trans. Roy. Soc. London A305 225-247.

Bizzi L A, Smith C B, Meyer H O A, Armstrong R and de Wit M J 1994 Mesozoic kimberlites and related rocks in southwestern Sao Francisco craton, Brazil: A case for local mantle reservoirs and their interaction. In: Proceedings of the fifth international kimberlite Conference, Araxa, Brasilia; (eds) Meyer H O A and Leonardos O H, CRPM Special Publication 2/91 166-171.

Carlson R W, Esperanca S and Svisero D P 1996 Chemical and Os isotopic study of Cretaceous potassic rocks from southern Brazil; Contrib. Mineral. Petrol. 125 393-405.

Chakraborty C and Bhattacharya A 1996 The Vindhyan Basin: An overview in the light of current perspectives; In: Recent advances in Vindhyan geology (ed.) Bhattacharya A, Geol. Soc. India Memoir 36 301-312.
Chakraborty P P, Banerjee S, Das N G, Sarkar S and Bose P K 1996 Volcaniclastics and their sedimentalogical bearing in Proterozoic Kaimur and Rewa Groups in Central India; In: Recent advances in Vindhyan geology (ed.) Bhattacharya A, Geol. Soc. India Memoir 36 59-76.

Chalapathi Rao N V 2005 A petrological and geochemical reappraisal of the mesoproterozoic diamondiferous Majhgawan pipe of central India: evidence for transitional kimberlite-orangeite (group II kimberlite)-lamproite rock type; Mineral. Petrol. 84(2) 69-106.

Chalapathi Rao N V, Gibson S A, Pyle D M and Dickin A P 2004 Petrogenesis of Proterozoic lamproites and kimberlites from the Cuddapah basin and Dharwar craton, southern India; J. Petrol. 45 907-948.

Chaterji G C 1971 Intensification of exploration for diamond; Geol. Surv. India Misc. Publ. 19 19-28.

Chatterjee A K and Rao K S 1995 Majhgawan diamondiferous pipe, Madhya Pradesh, India - A review; J. Geol. Soc. India 45 175-189.

Clarke T C, Smith C B, Bristow J W, Skinner E M W and Viljoen K S 1991 Isotopic and geochemical variation in kimberlites from the south western craton margin, Prieska area, South Africa; Extended Abstracts, Fifth Intern. Kimb. Conf., Araxa, Brazil, CPRM Spec. Publ. 2/91 46-48

Clement C R 1982 A comparative geological study of some major kimberlite pipes in northern Cape and Orange Free State. Unpublished Ph.D. Thesis, University of Cape Town, South Africa.

Crawford A R and Compston W 1970 The age of the Vindhyan system of peninsular India; J. Geol. Soc. London $125351-371$.

Dasgupta P and Phukan S 1971 Mineralogy of the altered diamondiferous pipe rock at Panna, M.P.; Geol. Surv. India Misc. Publ. 19 114-119.

Dawson J B and Smith J V 1977 The MARID (micaamphibole-rutile-ilmenite-diopside) suite of xenoliths in kimberlite; Geochem. Cosmochim. Acta 41 309-323.

Dobson D P, Jones A P, Rabe R, Sekine T, Kurita K, Taniguchi $\mathrm{T}$, Kondo $\mathrm{T}$, Kato $\mathrm{T}$, Shimomura $\mathrm{O}$ and Urakawa S 1996 In-situ measurement of viscosity and density of carbonate melts at high pressure; Earth Planet. Sci. Lett. 143 207-215.

Dowall D P, Nowell G M, Pearson D G, Kjarsgaard B A and Carlson J A 2000 The nature of kimberlite source regions: a Hf-Nd isotope study of Slave craton kimberlites; J. Conf. Abstr. 5(2) 357.

Dubey V S and Merh S 1949 Diamondiferous plug of Majhgawan in Central India; Quart. J. Geol. Min. Met. Soc. India 21 1-5.

Edwards D, Rock N M S, Taylor W R, Griffin W J and Ramsay R R 1992 Mineralogy and petrology of the Aries diamondiferous kimberlite pipe, central kimberley block, Western Australia; J. Petrol. 3 1157-1191.

Emeleus C H and Andrews J R 1975 Mineralogy and petrology of kimberlite dyke and sheet intrusions and included peridotite xenoliths from SW Greenland; Phys. Chem. Earth 9 179-198.

England P and Houseman G 1984 On the geodynamic setting of kimberlite genesis; Earth Planet. Sci. Lett. 67 109-122.

Foley S F 1992 Vein-plus-wall-rock melting mechanisms in the lithosphere and the origin of potassic alkaline magmas; Lithos 28 435-438.

Foley S F, Venturelli G, Green D H and Toscani L 1987 The ultra-potassic rocks: characteristics, classification and constraints for petrogenetic models; Earth Sci. Rev. 24 81-134. 
Fraser K J 1987 Petrogenesis of kimberlites from South Africa and lamproites from Western Australia and North America; Unpublished Ph.D. Thesis, The Open University, Milton Keynes, UK.

Fraser K J, Hawkesworth C J, Erlank A J, Mitchell R H and Scott-Smith B H $1985 \mathrm{Sr}, \mathrm{Nd}$ and Pb isotope and minor element geochemistry of lamproites and kimberlites; Earth Planet. Sci. Lett. 76 57-70.

Ghosh R N 2002 Bundelkhand granite gneiss terrain - a repository for kimberlite magmatism in the central Indian peninsular shield; In: Proc. Int. Conf. on Diamonds and Gemstones (SAEEG) Raipur, Chattisgarh, pp. 30-33.

Gibson S A, Thompson R N, Leonardos O H, Dickin A P, Mitchell J G 1995 The Late Cretaceous impact of the Trindade mantle plume: evidence from large-volume, mafic, potassic magmatism in SE Brazil; J. Petrol. 36 $189-229$.

Grantham D R 1964 The diamond deposits of Panna, Central India; Indus Diamond Rev. 24 30-35.

Greenwood J C, Gibson S A, Thompson R N, Weska R K and Dickin A P 1999 Cretaceous kimberlites from the Paranatinga-Batovi region, Central Brazil: Geochemical evidence for subcratonic lithosphere mantle heterogeneity; Proc. of the Seventh Int. Kimberlite Conf. Cape Town, South Africa 1 291-298.

Gupta A K, Yagi K, Lovering J and Jaques A L 1986 Geochemical and microprobe studies of the diamond-bearing ultramafic rocks from central and south India; Geol. Soc. Austral. Abstr. 16 27-29.

Gurney J J and Ebrahim S 1973 Chemical composition of Lesotho kimberlites; In: Lesotho kimberlites (ed.) Nixon P H, Lesotho National Development Corporation, Maseru, pp. 280-284.

Haggerty S E 1994 Super kimberlites: a geodynamic window to the earth's core; Earth Planet. Sci. Lett. 122 $57-69$.

Haggerty S E 1999 Diamond formation and kimberlite clan magmatism; Geochem. Soc. Spec. Publ. 6 105-123.

Haggerty S E and Birkett T 2004 Geological setting and chemistry of kimberlite clan rocks in the Dharwar craton, India; Lithos $\mathbf{7 6} 535-549$.

Halder D and Ghosh D B 1978 Tectonics of kimberlites around Majhgawan, M.P., India; Geol. Surv. India Misc. Publ. 34(3) 1-13.

Halder D and Ghosh D B 1981 Kimberlites from Panna, M.P., India: Petrology and emplacement history; Proc. IV Reg. Cong. on Geology Mineral and Energy Resources of SE Asia, Manila, Phillipines, pp. 65-87.

Haskin L A, Haskin M A, Frey F A and Wilderman T R 1968 Relative and absolute abundances of Rare Earths; In: Origin and distribution of elements (ed.) Ahrens L H, (New York: Pergamon) pp. 889-912.

Hawkesworth C J, Fraser K J and Rogers N W 1985 Kimberlites and lamproites: extreme products of mantle enrichment processes; Trans. Geol. Soc. S. Africa 88 439-447.

Hukku B M 1971 Evidence of volcanism and probable occurrence of volcanic plugs in the Lower Vindhyans of Banda district, U.P. and Rewa district, M.P.; Ind. Miner. 33 $120-121$.

Hammond A L and Mitchell R H 2002 Accessory mineralogy of orangeite from Swartruggens, South Africa; Mineral. Petrol. 76 1-19.

Indian Bureau of Mines 1996 Diamond; Bulletin 26 62.

Janse A J A 1992 Archons and Cratons: Modern ideas on tectonic and structural control of economic kimberlites; Proc. Int. Round Table Conf. on Diamond Exploration and Mining (26 8527 Nov., New Delhi) (unpaginated).
Jaques A L, Lewis J D and Smith C B 1986 The kimberlites and lamproites of Western Australia, Geol. Surv. Western. Australia; Geol. Surv. Western. Australia Bull. 132 268.

Jaques A L, Sun S-S and Chappell B W 1989 Geochemistry of Argyle (AK1) lamproite pipe, Western Australia; Geol. Soc. Australia Spec. Publ. 14 170-188.

Jaques A L and Milligan P R 2003 Patterns and controls on the distribution of diamond pipes in Australia; Proc. 8th Int. Kimberlite Conference, Victoria, British Columbia, Canada (unpaginated).

Kaila K L, Murthy P R K and Mall D M 1989 The evolution of the Vindhyan basin vis-à-vis the Narmada-Son lineament, central India, from deep seismic soundings; Tectonophys. 162 277-289.

Kailasam L N 1971 Geophysics in diamond exploration; Geol. Surv. India Misc. Publ. 19 60-68.

Kale V S 1991 Constraints on the evolution of the Purana basins of Peninsular India; J. Geol. Soc. India $\mathbf{3 8}$ 231-252.

Kaminsky F V, Sablukov S M, Sablukova I L and Channer D M D R 2004 Neoproterozoic 'anomalous' kimberlites of Guaniamo, Venezuela:mica kimberlites of 'isotopic transitional' type; Lithos 76 565-590.

Kent R W, Kelley S P and Pringle M S 1998 Mineralogy and ${ }^{40} \mathrm{Ar} /{ }^{39} \mathrm{Ar}$ geochronology of orangeites (Group II kimberlites) from the Damodar Valley, Eastern India; Mineral Mag. 62 313-323.

Kharikov A D, Zherdev P Y, Makhotkin I L, Shermeyev V F 1991 Composition of the diamond bearing rocks of the Majhgawan pipe, Central India; Izvestia ANSSR, Seriya Seriya Geologicheskaya 3 123-132.

Kramers J D, Smith C B, Lock N P, Harmon R S and Boyd F R 1981 Can kimberlite be generated from an ordinary mantle?; Nature 291 53-56.

Krishnan M S and Swaminath J 1959 The Great Vindhyan basin of northern India; J. Geol. Soc India 1 10-30.

Kresten P and Paul D K 1976 Mineralogy of Indian kimberlites - a thermal and X-ray study; Can. Mineral. 14 487-490.

Lehmann B, Mainkar D and Belyatsky B 2002 Reconnaissance study of the very large Tokapal crater-facies kimberlite system, Chattisgarh, India; Proc. Int. Conf. on Diamonds and Gemstone (SAEEG) Raipur, Chattisgarh $1-5$.

Le Roex A P, Bell D R and Davis P 2003 Petrogenesis of Group I kimberlites from Kimberley, South Africa: evidence from bulk-rock geochemistry; J. Petrol. 44 2261-2286.

Lewis $\mathrm{H} \mathrm{C} 1887$ On a diamondiferous peridotite and the genesis of the diamond; Geol. Mag. 4 22-24.

Madhavan V 2002 The present status of lamproites from the central and eastern Indian states: An identity crisis in the offing?; Proc. Int. Conf. on Diamonds and Gemstone (SAEEG). Raipur, Chattisgarh 14-16.

Mahotkin I L, Gibson S A, Thompson R N, Zhuravlev D Z and Zherdev P U 2000 Late Devonian Diamondiferous Kimberlite and Alkaline Picrite (Proto-kimberlite?) Magmatism in the Arkhangelsk Region, NW Russia; J. Petrol. 41 201-227.

Mathur S M 1953 Diamond mining and recovery at the Majhgawan mine in Panna, Vindhyan Pradesh; Ind. Miner. 7 34-42.

Mathur S M 1958 Geology of the Panna diamond deposits; Rec. Geol. Surv. India 77 787-818.

Mathur S M and Singh H N 1963 Geology and sampling of the Majhgawan diamond deposit, Panna district, M.P; Bull. Geol. Surv. India 21 50-52. 
Mathur S M and Singh H N 1971 Petrology of the Majhgawan pipe rock; Geol. Surv. India Misc. Publ. 19 78-85.

Maury R, Defant C and Joron M J 1992 Metasomatism of the sub-arc mantle inferred from trace elements in Phillipines xenoliths; Nature 360 660-661.

McCulloch M T, Jaques A L, Nelson D R and Lewis J D $1983 \mathrm{Nd}$ and Sr isotopes in kimberlites and lamproites from western Australia: an enriched mantle origin; Nature 302 400-403.

McKenzie D P 1978 Some remarks on the development of sedimentary basins; Earth Planet. Sci. Lett. 40 25-32.

McKenzie D 1989 Some remarks on the movement of small melt fractions in the mantle; Earth Planet. Sci. Lett. 95 $53-72$.

Medlicott H S 1859 Geology of the state of Panna, principally with reference to the diamond bearing deposits; Rec. Geol. Surv. India 33 261-314.

Menzies M A and Wass S Y $1983 \mathrm{CO}_{2}$ and LREE-rich mantle below eastern Australia: a REE and isotopic study of alkaline magmas and apatite-rich mantle xenoliths from the Southern Highlands Province, Australia; Earth Planet. Sci. Lett. 65 287-302.

Merh S 1952 Further study of the Majhgawan diamond mine, Panna state, Central India; J. Geol. Min. Met. Soc. India 24 125-132.

Middlemost E A K and Paul D K 1984 Indian kimberlites and genesis of kimberlite; Chem. Geol. 47 249-260.

Mishra D C, Lakshman G, Rao M B S V and Gupta S B 1995 Analysis of the gravity-magnetic data around NagaurJhalawar geotransect; Geol. Soc. India Memoir $\mathbf{3 1}$ 345-351.

Mitchell R H 1986 Kimberlites: Mineralogy, Geochemistry and petrology, (New York: Plenum Press) 442.

Mitchell R H 1995a Kimberlites, orangeites and related rocks; Plenum Press, New York, 406.

Mitchell R H 1995b Melting experiments on a sanidine phlogopite lamproite at 4-7 GPa and their bearing on the sources of lamproite magmas; J. Petrol. 36 $1455-1474$.

Mitchell R H and Bergman S C 1991 Petrology of lamproites, Plenum Press, New York, 447.

Mitra N D 1996 Some problems of Vindhyan geology; Geol. Soc. India Memoir 36 1-4.

Moore R O, Gurney J J, Griffin W L and Shimizu N 1991 Ultra-high pressure garnet inclusions in Monastery diamonds: trace element abundance patterns and conditions of origin; Eur. J. Mineral. 3 213-230.

Mukherjee A, Rao K S, Bandyopadhyay D and Roy G 1997 Chemistry of garnet and ilmenite from Majhgawan diamondiferous pipe, Panna district vis-à-vis diamond potential and preservation; J. Geol. Soc. India $\mathbf{5 0}$ 441-448.

Murphy D T, Collerson K D and Kamber B S 2002 Lamproites from Gaussberg, Antarctica: Possible Transition Zone Melts of Archaean Subducted Sediments; J. Petrol. 43 981-1001.

Naqvi S M and Rogers J J W 1987 Precambrian Geology of India; Oxford Monographs on Geology and Geophysics 6 223.

Nowell G M, Pearson D G, Bell D R, Carlson R W, Smith C B, Kempton P D and Noble S R 2004 Hf isotope systematics of kimberlites and their megacrysts: new constraints on their source regions; J. Petrol. 45(8) 1583-1612.

Paul D K 1979 Isotopic composition of Strontium in Indian kimberlites; Geochim. Cosmochim. Acta 43 389-394.

Paul D K 1991 Indian kimberlites and lamprophyres: Mineralogical and chemical aspects; J. Geol. Soc. India $\mathbf{3 7}$ 221-238.
Paul D K, Rex D C and Harris P G 1975a Chemical characteristics and K-Ar ages of Indian kimberlites; Geol. Soc. Amer. Bull. 86 364-366.

Paul D K, Potts P J, Gibson I L and Harris P G 1975b Rare earth abundances in Indian kimberlites; Earth Planet. Sci. Lett. 25 151-158.

Peacock S M 1990 Fluid processes in subduction zones; Science 248 329-337.

Prasad B 1976 Volcanic activity during Lower Vindhyan Period, Chittorgarh dist., Rajasthan; Ind. Mineral. 30(4) 73-75.

Prasad B 1981 A review of the Vindhyan Super Group in South-eastern Rajasthan; Geol. Surv. India Misc. Publ. 50 31-40.

Prasad B 1984 Geology, sedimentation and palaeogeography of the Vindhyan Super Group, S.E. Rajasthan; Geol. Surv. India Memoir 116(1) 1-107.

Ravi Shanker, Nag S, Ganguly A, Absar A, Rawat B P and Singh G S 2001 Are Majhgawan-Hinota pipe rocks truly Group - I kimberlite?; Proc. Ind. Acad. Sci. (Earth Planet. Sci.) 110(1) 63-76.

Ravi Shanker, Nag S and Rawat B P 2002 Nomenclature problems in kimberlites - A case study from Majhgawan, Panna district, Madhya Pradesh, India; Proc. Int. Conf. on Diamonds and Gemstone (SAEEG). Raipur, Chattisgarh, pp. 119-122.

Ray J S, Veizer J and Davis W J 2003 C, O, Sr and Pb isotope systematics of carbonate sequences of the Vindhyan Super Group, India: age, diagenesis, correlations and implications for global events; Precamb. Res. 121 $103-140$.

Raza M, Casshyap S M and Khan A 2001 Accretionary Lapilli from the Basal Vindhyan volcanic sequence, south of Chittaurgarh, Rajasthan and their implication; J. Geol. Soc. India 57 77-82.

Raza M, Casshyap S M and Khan A 2002 Geochemistry of Mesoproterozoic Lower Vindhyan shales from Chittaurgarh, Southeastern Rajasthan and its bearing on source rock composition, palaeoweathering conditions and tectono-sedimentary environments; J. Geol. Soc. India $60505-518$.

Ringwood A R, Kesson S E, Hibberson W and Ware N 1992 Origin of kimberlites and their related magmas; Earth Planet. Sci. Lett. 113 521-538.

Rock N M S 1991 Lamprophyres, Blackie and Sons Ltd., Glasgow 285.

Rock N M S and Paul D K 1989 "Lamprophyres", "lamproites" and "kimberlites" in India: a bibliography and preliminary reappraisal; Geol. Soc. India Memoir $\mathbf{1 5}$ 291-311.

Roy A and Devarajan M K 2000 A reappraisal of the stratigraphy and tectonics of the Proterozoic Mahakoshal belt, Central India. In: Precambrian crust in eastern and central India. UNESCO-IUGS-IGCP-368; Geol. Surv. India Spec. Publ. 17 79-97.

Roy A and Hanuma Prasad M 2001 Precambrian of Central India: a possible tectonic model; Geol. Surv. India Spec. Publ. 64 177-197.

Rudnick R L, McDonough W F and Chappell B W 1993 Carbonatite metasomatism in northern Tanzanian mantle: petrographic and geochemical characteristics; Earth Planet. Sci. Lett. 114 463-475.

Scott B H 1979 Petrogenesis of kimberlites and associated potassic lamprophyres from central west Greenland; In: Kimberlites, pipes and diamonds: their geology, petrology and geochemistry (eds) Boyd F $\mathrm{R}$ and Meyer $\mathrm{H} \mathrm{O} \mathrm{A}$ American Geophysical Union, Washington 1 190-225.

Scott-Smith BH 1989 Lamproites and kimberlites in India; Neus Jahrb. Mineral. Abh. 161(2) 193-225. 
Scott-Smith B H, Skinner E M W and Loney P E 1989 The Kapamba lamproites of the Luangwa valley, eastern Zambia; Geol. Soc. Australia Spec. Publ. 14 189-205.

Scott-Smith B H 1992 Kimberlites and lamproites: compared and contrasted; Proc. Int. Round Table Conf. On Diamond Expl. Mining (26 \& 27 Nov., New Delhi) (unpaginated).

Scott-Smith B H and Skinner E M W 1984 Diamondiferous lamproites; J. Geol. 92 433-438.

Sinor K P 1930 The Diamond Mines of Panna state in Central India; The Times of India Press, Bombay 189.

Skinner E M W 1989 Contrasting Group I and II kimberlite petrology: Towards a genetic model for kimberlites; Geol. Soc. Australia Spec. Publ. 14(1) 528-544.

Skinner E M W, Clement C R, Gurney J J, Apter D B and Hatton C J 1992 The distribution and tectonic setting of Southern African kimberlites; Russ. Geol. Geophys. 33 $26-31$

Skinner E M W, Viljoen K S, Clarke T C and Smith C B 1994 The petrography, tectonic setting and emplacement ages of kimberlites in the south Western border region of the Kaapvaal craton, Prieska area; In: Kimberlites, related rocks and mantle xenoliths (eds) Meyer H O A and Leonardos O H, CPRM Spec. Publ. IA 80-97.

Smith C B $1983 \mathrm{~Pb}, \mathrm{Sr}$ and Nd isotopic evidences for sources of southern African Cretaceous kimberlites; Nature 304 $51-54$

Smith C B, Allsopp H L, Kramers J D, Hutchinson G and Roddick J C 1985 Emplacement ages of JurassicCretaceous South African kimberlites by the Rb-Sr method on phlogopite and whole-rock samples; Trans. Geol. Soc. South Africa 88 249-266.

Smith J V, Breunscholtz R and Dawson J B 1978 Chemistry of micas from kimberlites and xenoliths - I micaceous kimberlites; Geochim. Cosmochim. Acta 42 959-971.

Soni M K, Chakravorty S and Jain V K 1987 Vindhyan Super Group - a review; Geol. Soc. India Memoir 6 87-138.

Soni M K, Jha D K, Tiwari M, Singh A N, Agasty A and Pimprikar S D (2002) Geochemical prospecting for kimberlite in Panna diamond belt, M.P. 2002 Geochemical prospecting for kimberlite in Panna diamond belt, M.P;
Proc. Int. Conf. on Diamonds and Gemstone (SAEEG) Raipur, Chattisgarh, pp. 110-111.

Spriggs A J 1988 An isotopic and geochemical study of kimberlites and associated alkaline rocks from Namibia; Unpublished Ph.D. thesis, University of Leeds, UK.

Tainton K M and McKenzie D 1994 The generation of kimberlites, lamproites and their source rocks; J. Petrol. 35 787-817.

Tainton K M 1992 The petrogenesis of Group-2 kimberlites and lamproites from the Northern Cape province, South Africa, Unpublished Ph.D Thesis, Cambridge University, UK.

Taylor W R, Tompkins L A and Haggerty S E 1994 Comparative geochemistry of West African kimberlites: evidence for a micaceous kimberlite end member of sub-lithospheric origin; Geochim. Cosmochim. Acta $\mathbf{5 8}$ 4017-4037.

Thompson R N, Morrison M A, Hendry G L and Parry S J 1984 An assessment of the relative roles of crust and mantle in magma genesis: an elemental approach; Phil. Trans. Roy. Soc. London A310 549-590.

Thompson R N, Leat P T , Morrison M A, Hendry G L and Gibson S A 1990 Strongly potassic mafic potassic mafic magmas from lithospheric mantle sources during continental extension and heating: evidence from Miocene minettes of NW Colarado, USA; Earth Planet. Sci. Lett. 98 139-153.

Venkataraman K 1960 Quart. J. Geol. Min. Met. Soc. India 32(1) 1-15.

Wagner P A 1914 The diamond fields of South Africa; Transvaal Leader, Johannesburg, South Africa, pp. 355

Watson E B, Brenan J M and Baker D R 1990 Distribution of fluids in the continental mantle; In: Continental mantle, (ed.) Menzies M A, Oxford Monographs on Geology and Geophysics 16 111-122.

Wilson M, Rosenbaum J M, Dunworth E A 1995 Melilitites: partial melts of the thermal boundary layer?; Contrib. Mineral. Petrol. 119 181-196.

Woolley A R, Bergman S C, Edgar A D, Le Bas M J, Mitchell R H, Rock N M S and Scott-Smith B H 1996 Classification of lamprophyres, lamproites, kimberlites and the kalsilitic, melilitic and leucitic rocks; Can. Mineral. 34 175-186. 